\title{
Framework for a U.S. Geological Survey Hydrologic Climate-Response Program in Maine
}
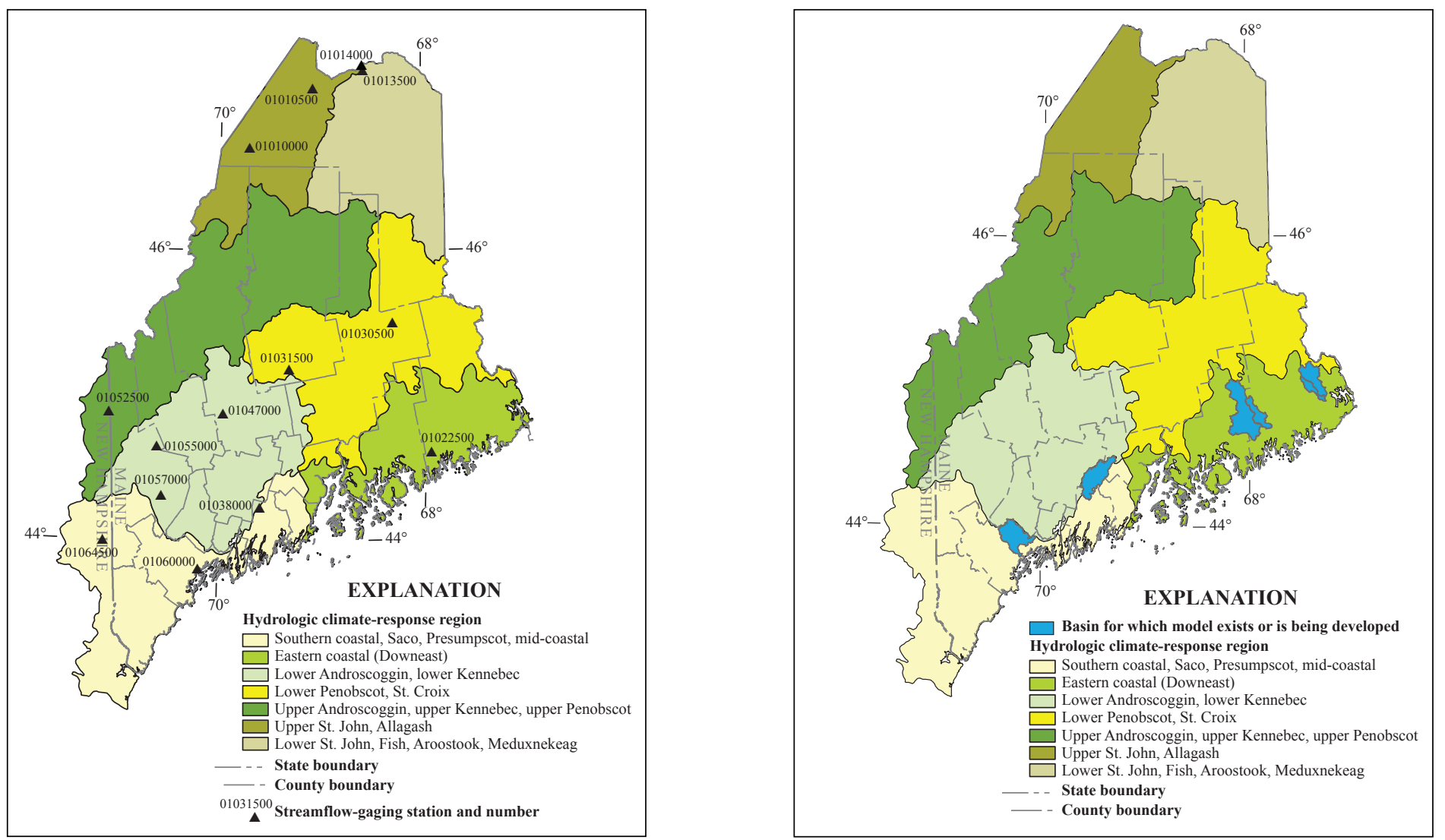

Open-File Report 2009-1115 



\section{Framework for a U.S. Geological Survey Hydrologic Climate-Response Program in Maine}

By Glenn A. Hodgkins, Robert M. Lent, Robert W. Dudley, and Charles W. Schalk

Open-File Report 2009-1115 


\title{
U.S. Department of the Interior \\ KEN SALAZAR, Secretary
}

\author{
U.S. Geological Survey \\ Suzette M. Kimball, Acting Director
}

U.S. Geological Survey, Reston, Virginia: 2009

For product and ordering information:

World Wide Web: http://www.usgs.gov/pubprod

Telephone: 1-888-ASK-USGS

For more information on the USGS - the Federal source for science about the Earth,

its natural and living resources, natural hazards, and the environment:

World Wide Web: http://www.usgs.gov

Telephone: 1-888-ASK-USGS

Suggested citation:

Hodgkins, G.A., Lent, R.M., Dudley, R.W., and Schalk, C.W., 2009, Framework for a U.S. Geological Survey hydrologic climate-response program in Maine: U.S. Geological Survey Open-File Report 2009-1115, 29 p.

Any use of trade, product, or firm names is for descriptive purposes only and does not imply endorsement by the U.S. Government. Use of company names is for identification purposes only and does not imply responsibility.

Although this report is in the public domain, permission must be secured from the individual copyright owners to reproduce any copyrighted material contained within this report. 


\section{Contents}

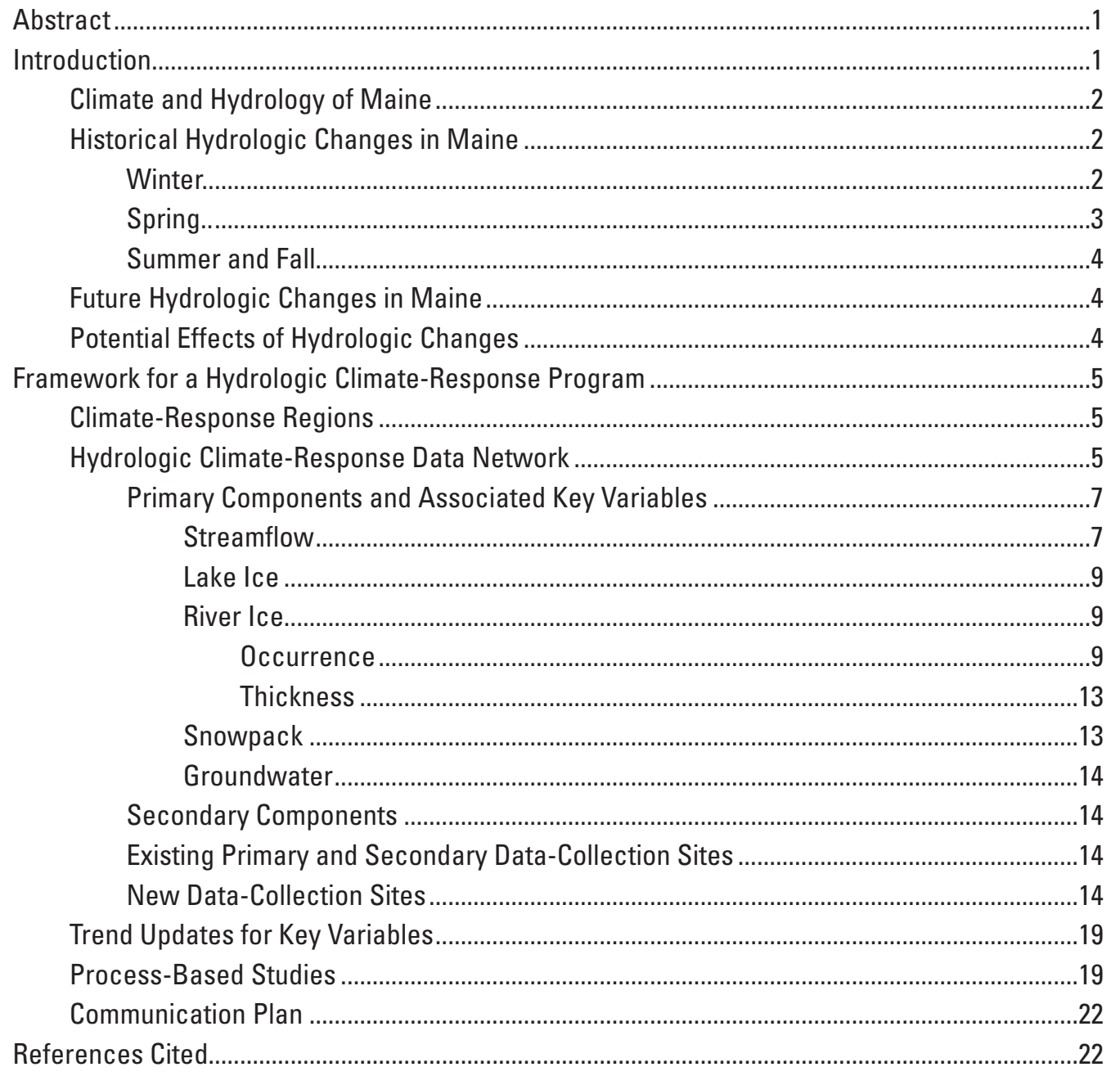




\section{Figures}

1-3. Graphs showing-

1. Annual average snowpack density at four sites in western Maine/northern New Hampshire for the March 15 sampling window (the 15-day period centered on March 15), 1914-2004

2. Annual winter-spring center-of-volume dates (a measure of streamflow timing) for the Piscataquis River in central Maine, 1903-2000

3. Annual lake ice-out dates for Damariscotta Lake, midcoastal Maine, 1837-2008

4-13. Maps showing-

4. Location of hydrologic climate-response regions in Maine ..

5. Location of long-term streamflow-gaging stations that drain relatively natural basins in and near Maine.

6. Location of lakes with long-term ice-out data in Maine ..........................................10

7. Location of rivers with long-term ice-occurrence data in and near Maine ............12

8. Location of long-term snowpack sites in and near Maine .......................................15

9. Location of Native American headquarters in Maine .............................................16

10. Location of U.S. Department of Interior and Agriculture lands in and near Maine

11. Location of major surface water suppliers in Maine ...........................................18

12. Location of drainage basins in Maine with rainfall-runoff models .........................20

13. Rainfall-runoff model subareas for two drainage basins in eastern coastal Maine.

\section{Tables}

1. Hydrologic climate-response regions in Maine

2. Long-term streamflow-gaging stations on Maine rivers that drain relatively natural basins..

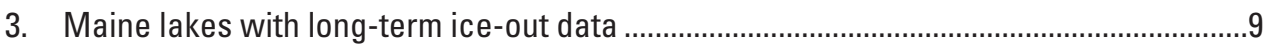

4. Maine rivers with long-term ice occurrence data ...........................................................1

5. Long-term snowpack sites in and near Maine .............................................................14

6. Examples of annual cycles of trend updates for key variables of hydrologic components 


\section{Conversion Factors}

\begin{tabular}{lcl}
\hline & Multiply & \multicolumn{1}{c}{ By } \\
\hline & \multicolumn{1}{c}{ Length } & \\
\hline inch (in.) & 2.54 & centimeter $(\mathrm{cm})$ \\
inch (in.) & 25.4 & millimeter $(\mathrm{mm})$ \\
foot (ft) & 0.3048 & meter $(\mathrm{m})$ \\
mile (mi) & 1.609 & kilometer $(\mathrm{km})$ \\
\hline
\end{tabular}

Temperature in degrees Fahrenheit $\left({ }^{\circ} \mathrm{F}\right)$ may be converted to degrees Celsius $\left({ }^{\circ} \mathrm{C}\right)$ as follows:

${ }^{\circ} \mathrm{C}=\left({ }^{\circ} \mathrm{F}-32\right) / 1.8$ 
-- THIS PAGE INTENTIONALLY LEFT BLANK -- 


\title{
Framework for a U.S. Geological Survey Hydrologic Climate-Response Program in Maine
}

\author{
By Glenn A. Hodgkins, Robert M. Lent, Charles W. Schalk, and Robert W. Dudley
}

\section{Abstract}

This report presents a framework for a U.S. Geological Survey (USGS) hydrologic climate-response program designed to provide early warning of changes in the seasonal water cycle of Maine. Climate-related hydrologic changes on Maine's rivers and lakes in the winter and spring during the last century are well documented, and several river and lake variables have been shown to be sensitive to air-temperature changes. Monitoring of relevant hydrologic data would provide important baseline information against which future climate change can be measured.

The framework of the hydrologic climate-response program presented here consists of four major parts: (1) identifying homogeneous climate-response regions; (2) identifying hydrologic components and key variables of those components that would be included in a hydrologic climate-response data network - as an example, streamflow has been identified as a primary component, with a key variable of streamflow being winter-spring streamflow timing; the data network would be created by maintaining existing USGS data-collection stations and establishing new ones to fill data gaps; (3) regularly updating historical trends of hydrologic data network variables; and (4) establishing basins for process-based studies.

Components proposed for inclusion in the hydrologic climate-response data network have at least one key variable for which substantial historical data are available. The proposed components are streamflow, lake ice, river ice, snowpack, and groundwater. The proposed key variables of each component have extensive historical data at multiple sites and are expected to be responsive to climate change in the next few decades. These variables are also important for human water use and (or) ecosystem function.

Maine would be divided into seven climate-response regions that follow major river-basin boundaries (basins subdivided to hydrologic units with 8-digit codes or larger) and have relatively homogeneous climates. Key hydrologic variables within each climate-response region would be analyzed regularly to maintain up-to-date analyses of year-to-year variability, decadal variability, and longer term trends. Finally, one basin in each climate-response region would be identified for process-based hydrologic and ecological studies.

\section{Introduction}

It is important to monitor hydrologic systems in the United States that could change dramatically over the short term as a result of climate change. Many ecological effects of climate change can be well understood only if hydrologic data networks are in place. Because of its humid, temperate climate and its substantial annual snowpack, Maine's seasonal water cycle is sensitive to small changes in air temperature (Hodgkins and others, 2003b). Monitoring of relevant hydrologic data provides important baseline information against which future climate change can be measured.

A series of recent investigations by the U.S. Geological Survey has documented changes in several components of the water cycle in Maine during the last 30 to 40 years (discussed in the Historical Hydrologic Changes in Maine section).

Results from climate projections input to hydrologic models indicate that changes will continue to occur in the future (discussed in the Future Hydrologic Changes in Maine section). The effects of these past and future changes on habitats and ecosystems are largely unknown but may include a change in the timing of freshwater discharge to estuaries, decreased summer lake hypolimnion oxygen levels, and increased stress to river ecosystems, leading to possible endangerment or loss of species. The trends could affect species at the edge of their range in Maine, such as Atlantic salmon and Canada lynx. These effects are described in more detail in the following sections.

This report presents a framework for a USGS hydrologic climate-response program. This program is designed to provide early warning of changes in the seasonal water cycle of Maine. The program would be created by maintaining a network of existing USGS data-collection stations and establishing new ones to fill data gaps. In this report, proposed hydrologic variables and data-collection stations to be included within homogeneous climate-response regions are discussed. Hydrologic data from the network would be analyzed periodically to maintain up-to-date analyses of trends and variability and an appropriate basin in each region in which to begin process-based studies would be identified.

The USGS has been collecting hydrologic data in Maine for more than a century. Since 2000, historical data for many 
variables have been analyzed to determine their appropriateness for use in computing climate-related trends and then have been used to compute trends. This data collection and analysis experience was used to develop the framework for a USGS hydrologic climate-response program in Maine. Not all hydrologic variables have been systematically analyzed for their appropriateness for computing climate-related trends, however, and therefore the level of detail presented in this report varies among hydrologic components. It is anticipated that a USGS hydrologic climate-response program in Maine would be modified as understanding of the effects of climate change on hydrology in Maine improves.

\section{Climate and Hydrology of Maine}

The climate of Maine is complex and variable in both space and time. Latitude, proximity to the Atlantic Coast, and variations in land-surface elevation have a major effect on the climate (New England Regional Assessment Group, 2001). Maine is about halfway between the equator and the North Pole and is affected by warm, moist air from the south and cold, dry air from the north. The Atlantic Ocean moderates air temperatures in both winter and summer. In winter, the ocean variably influences the location of snow/rain boundaries. Despite the influence of the ocean, the prevailing air flow is not from the Atlantic Ocean, but from the drier North American continent. The mountainous topography of western and northwestern Maine influences both precipitation and air temperatures. Precipitation is higher on the windward side of mountains and lower on the leeward side, however, because storm-track directions through the mountains are highly variable; the windward and leeward areas differ for different storms. Air temperature decreases with elevation.

Maine generally has a temperate climate with mild summers and cold winters. From 1971 to 2000, the mean annual temperature in Maine was about $42^{\circ} \mathrm{F}$, with a range from $36^{\circ} \mathrm{F}$ in Allagash in northern Maine to $47^{\circ} \mathrm{F}$ in Sanford in southern Maine (National Oceanic and Atmospheric Administration, 2002). During the same period, statewide mean monthly temperatures ranged from $15^{\circ} \mathrm{F}$ in January to $67^{\circ} \mathrm{F}$ in July. Precipitation in Maine is fairly evenly distributed throughout the year. The mean annual precipitation from 1971 to 2000 was 43 in., ranging from 35 in. at Presque Isle in northern Maine to 57 in. at Acadia National Park in eastern coastal Maine.

The snowpack in Maine typically accumulates throughout the winter and reaches its maximum depth and water equivalent (the depth of water that would result if the snowpack were melted) in March or April. The median seasonal maximum depth of the snowpack for 1955 to 1992 varied from about $20 \mathrm{in}$. along the coast to more than $32 \mathrm{in}$. for the western mountains and northern Maine (Cember and Wilks, 1993). The average water equivalent on or near March 1 ranged from 3 to $5 \mathrm{in}$. along the coast to 7 to $9 \mathrm{in}$. for the western mountains and northern Maine (Loiselle and Hodgkins, 2002). The 109 data collection sites had an average of 43 years of record through 2000. Almost all of the data-collection sites were lower than $2,000 \mathrm{ft}$ in elevation and therefore do not represent the full range of average water equivalent in Maine, as many mountains have elevations higher than 2,000 ft.

Streamflows in Maine typically are highest in the spring, when rain falls on a ripe snowpack or on saturated soils. Streamflows recede as snowmelt ends and as evapotranspiration increases. This recession is frequently interrupted by runoff from rainstorms. Warm-season flows are usually lowest in August and September. In the fall, after evapotranspiration decreases substantially, repeated rains often saturate the soil, leading to high flows. Also in the fall, large amounts of rain can fall as a result of hurricanes, tropical storms, or their remnants. Winter flows are generally low in northern parts of Maine where winter precipitation typically falls as snow. Winter flows in southern parts of Maine can be more variable than flows in northern parts because of more winter rain.

\section{Historical Hydrologic Changes in Maine}

Climate-related seasonal hydrologic changes have been documented in Maine during the last 200 years. Many changes have been documented in winter and spring, whereas few consistent changes have been found in summer or fall. Overall, there is strong and consistent evidence of changes, all consistent with increasing temperatures, in late winter and spring in the last 30 to 40 years. There is some evidence of recent changes in mid-winter that are consistent with increasing temperatures (Hodgkins and others, 2005a; Huntington and others, 2003).

\section{Winter}

March mean streamflows increased significantly over time $(\mathrm{p}<0.1)$ at 12 of 14 streamflow-gaging stations in or near Maine; flows increased 76 to 185 percent at the seven stations with the longest continuous records (1920s or 1930s through 2002) (Hodgkins and Dudley, 2005). There were no stations with significant decreases. Eighteen of 23 snow-measurement sites in and near Maine with at least 50 years of records had a significant decrease $(p<0.1)$ in late-winter snowpack depth or an increase in snowpack density (Hodgkins and Dudley, 2006a). Increased snowpack density (fig. 1) for a set late-winter date indicates that the snow is more ready to melt.

The ratio of December through March snowfall to total precipitation decreased significantly $(\mathrm{p}=0.043)$ for the average of four U.S. Historical Climatology Network (USHCN) stations in northern New England from 1949 to 2000 (Huntington and others, 2004). The year-to-year ratio of snowfall to total precipitation in northern New England was correlated with air temperature $(\mathrm{r}=-0.45, \mathrm{p}=0.008)$ and total snowfall $(\mathrm{r}=0.48, \mathrm{p}=0.0003)$ but not with total precipitation $(\mathrm{r}=-0.078, \mathrm{p}=0.59)$. 
Huntington and others (2003) found a significant decrease over time $(\mathrm{p}=0.0021)$ in average ice thickness around February 28 on the Piscataquis River in central Maine. The ice thinned about 9 in. (45 percent) from 1912 to 2001. On average, for the nine rivers in northern New England (Maine, New Hampshire, and Vermont) with the longest records, riverice occurrence (total number of winter days with ice-affected flow) decreased significantly ( $p=0.0013$ ) from 1936 to 2000 (Hodgkins and others, 2005a). Most of the 20-day change in the total days of ice occurred from the 1960s to 2000. Year-toyear river-ice occurrence was highly correlated with winter air temperature $(\mathrm{r}=-0.70, \mathrm{p}<0.0001)$ and less highly correlated with winter precipitation $(r=-0.52, p<0.0001)$. More days of river ice were associated with colder temperatures and lower precipitation.

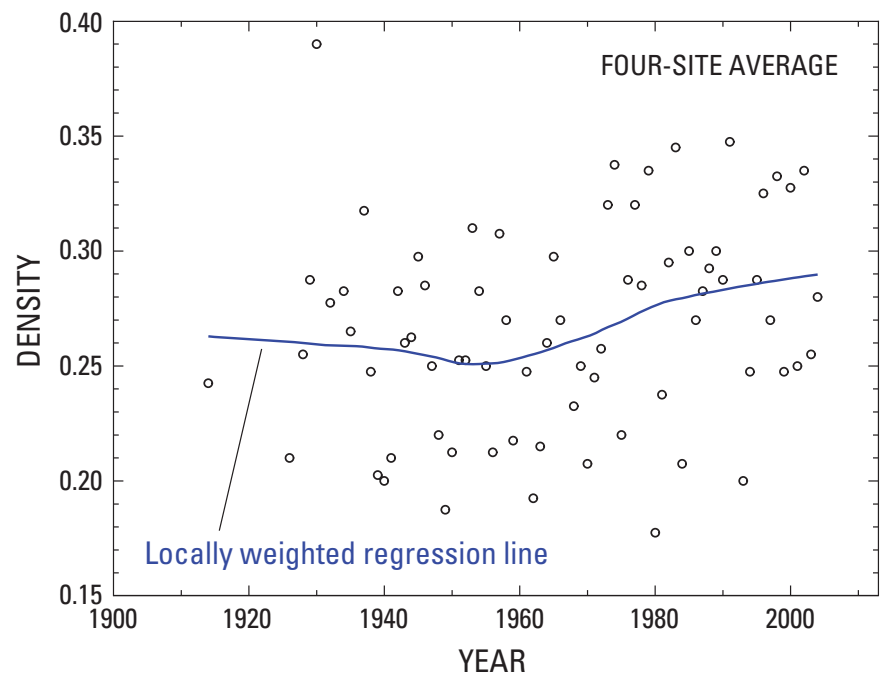

Figure 1. Annual average snowpack density at four sites in western Maine/northern New Hampshire for the March 15 sampling window (the 15-day period centered on March 15), 1914-2004.

\section{Spring}

Winter-spring streamflows became earlier in northern and mountainous sections of Maine during the 20th century, with most of the 1- to 2-week change occurring in the last 30 years (Dudley and Hodgkins, 2002; Hodgkins and others, 2003b; Hodgkins and Dudley, 2006b). Winter-spring streamflow timing is based on the center-of-volume date - the date, each year, that half of the winter-spring streamflow volume passes a streamflow-gaging station. Historical winter-spring streamflow timing for the Piscataquis River in central Maine is shown in figure 2. Year-to-year streamflow timing was highly correlated with March through April air temperature

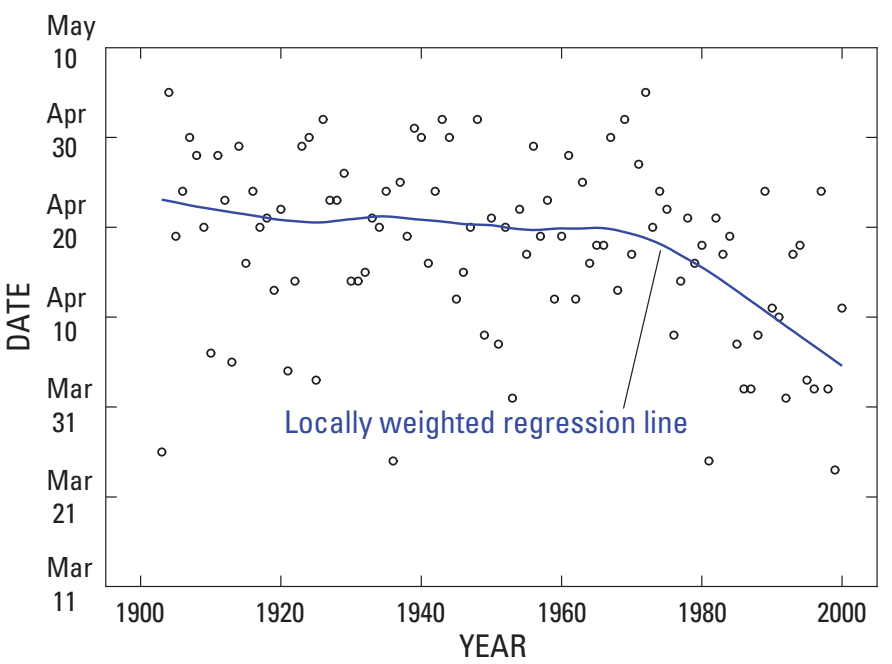

Figure 2. Annual winter-spring center-of-volume dates (a measure of streamflow timing) for the Piscataquis River in central Maine, 1903-2000.

$(r=-0.72, p<0.0001)$ (Hodgkins and others, 2003b). Higher air temperatures were associated with earlier streamflows. The highest correlation coefficient with precipitation was -0.37 $(\mathrm{p}=0.0018)$ with January precipitation. May streamflows decreased significantly $(p<0.1)$ at 9 of 14 stations in or near Maine; flows decreased 9 to 46 percent at the seven stations with the longest continuous records (Hodgkins and Dudley, 2005). There were no stations with significant increases. Annual peak flows often occur in the spring. Annual peak

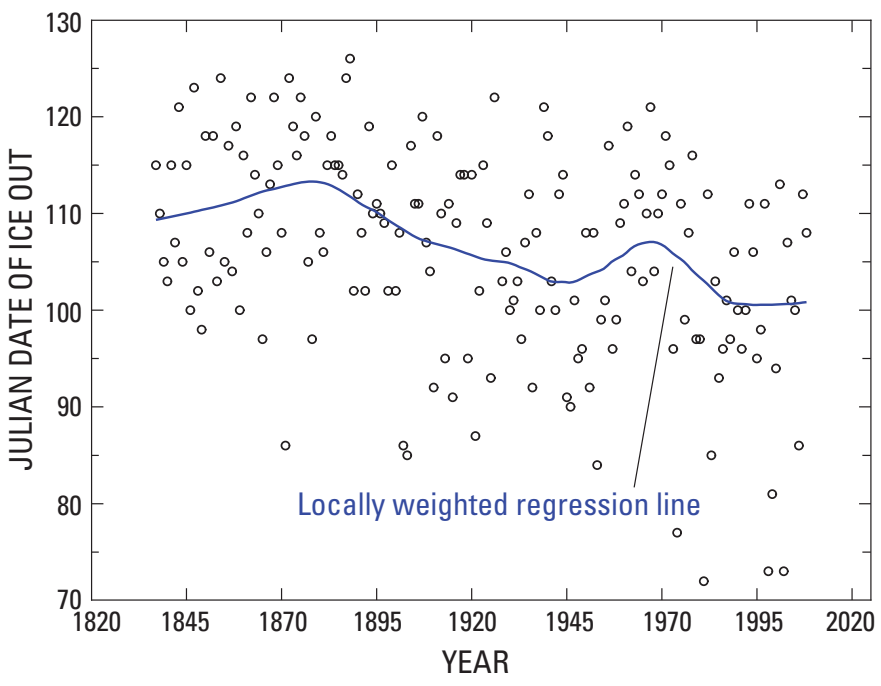

Figure 3. Annual lake ice-out dates for Damariscotta Lake, midcoastal Maine, 1837-2008. The Julian date is the sequential day of each year, starting on January 1. 
flows have increased significantly $(\mathrm{p}<0.1)$ during the last 50 to 100 years at some streamflow-gaging stations in Maine (Hodgkins and Dudley, 2005; Collins, 2009).

On average, for the nine rivers in northern New England with the longest records, river-ice breakup (the annual last spring days of ice-affected flow) became significantly earlier $(\mathrm{p}=0.0037)$ from 1936 to 2000. Most of the 11-day change in river-ice breakup occurred from the 1960s to 2000 (Hodgkins and others, 2005a). River-ice breakup was highly correlated with March through April air temperature $(r=-0.73$, $\mathrm{p}<0.0001$ ) and less highly correlated with precipitation (highest $r=-0.37, p=0.0027)$. Lake ice-out dates have become significantly earlier in Maine since the early $1800 \mathrm{~s}(\mathrm{p}<0.0001)$. Ice-out dates between 1850 and 2000 were 9 days earlier in northern/mountainous areas of Maine and 16 days earlier in southern areas (Hodgkins and others, 2002). Historical ice-out dates for Damariscotta Lake in midcoastal Maine are shown in figure 3 .

\section{Summer and Fall}

There is only weak evidence of historical summer or fall hydrologic changes in Maine. In summer, few significant changes during the last century in the magnitude, timing, or duration of low streamflows in Maine have been found (Dudley and Hodgkins, 2005; Hodgkins and Dudley, 2005; Hodgkins and others, 2005b). The timing and magnitude of low flows were much more highly correlated with summer precipitation than with air temperature (Hodgkins and others, 2005b). One of 11 rivers in Maine had significantly later $(\mathrm{p}<0.1)$ first fall days of river ice (Hodgkins and others, 2005a). Few significant changes in the timing or magnitude of fall high flows have been found (Hodgkins and others, 2003b; Dudley and Hodgkins, 2005; Hodgkins and Dudley, 2005). Fall streamflow timing is based on the center-of-volume date - the date, each year, that half of the fall streamflow volume passes a streamflow-gaging station.

\section{Future Hydrologic Changes in Maine}

Output from recent modeling using multiple atmosphereocean general circulation models, regionally down-scaled, and forced with low (B1), mid-high (A2), and high (A1FI) greenhouse-gas emission scenarios (Nakicenovic and others, 2000) provides a range of climate projections for the northeastern United States (Hayhoe and others, 2007). Hayhoe and others (2007) used climate projections as inputs to the variable infiltration capacity (VIC) hydrologic model to simulate future hydrologic responses.

Spring streamflow timing is expected to become earlier by 5 to 8 days, and annual 7-day low flows are expected to decrease by 1 to 4 percent between the periods 1961-90 and 2035-64 (Hayhoe and others, 2007). Projected low-flow changes by mid-century are very small; however, under the high-emissions scenario, larger decreases (11 percent) are projected by the period 2070-99. The number of short-term and long-term droughts (based on soil-moisture deficits) is expected to increase by 2035-64. Total annual snow-water equivalent and the number of days with snow per month are expected to decrease.

\section{Potential Effects of Hydrologic Changes}

Human water supply and transportation infrastructure in the northeastern United States may be affected by climate change. Earlier snowmelt runoff could cause sensitive water systems to be impacted because of less water availability in the summer. Managers of storage reservoirs may need to modify operation schedules or increase reservoir storage to allow successful operation in a potentially longer summer low-flow season. If summer low flows decrease, water-use conflicts will likely increase. Also, changes in streamflow in the northeastern United States may be important for other reasons; for example, higher winter flows can cause and have caused an increase in the frequency of mid-winter ice jams (Beltaos, 2002). River ice jams can cause major flooding and damage river infrastructure. Ice jams played a major role in Maine flooding in 1936 and 1991 (Grover, 1937; Wuebben and others, 1995).

Changes in the timing or magnitude of future streamflows will likely affect ecosystems. The ecological implications of changes in winter-spring streamflow timing in Maine are not well understood. One possible effect is a decrease in the survival rates of Atlantic salmon. If the peak spring migration of juvenile salmon from freshwater rivers (which is controlled by photoperiod, temperature, and flow) becomes out of phase by 2 weeks with optimal environmental conditions in rivers, estuaries, or the ocean, salmon survival could decrease substantially (McCormick and others, 1998). Changes in the timing of spring river flows may affect freshwater mixing in estuarine ecosystems. Earlier snowmelt and increases in summer evapotranspiration rates could shorten the annual periods of standing water used by amphibians for breeding in forested depressional wetlands (vernal pools). If summer low flows decrease, there could be higher water temperatures, reduced dissolved oxygen levels, and increased concentrations of contaminants (Bradbury and others, 2002). If river base flows (which are influenced by groundwater discharge) change, this could greatly affect cold-water fish because of changes in water temperature and dissolved-oxygen concentrations.

River ice is responsible for the creation of many erosional and depositional features in river channels and on channel floodplains. Physical disturbances associated with ice break-up scouring and flooding are primary to nutrient and organicmatter dynamics, water chemistry, and the abundance and diversity of river biota (Prowse and Beltaos, 2002). The succession of riparian vegetation is directly linked to the scouring effects of ice (Prowse and Beltaos, 2002). River-ice break-up 
is likely to have important effects on primary producers, consumers, and food-web dynamics of river biota, although detailed information describing the magnitude of their effects is scarce (Scrimgeour and others, 1994). Mortality, emigration, or displacement of fishes at all life stages is often the result of severe ice conditions, through the action of damming, scouring, associated flooding, or direct freezing (Power and others, 1993). Anchor ice, frazil (slush) ice that adheres to streambeds, can have serious effects on fish eggs and embryos developing within gravel beds (Prowse, 1994). Anchor ice does not form when surface-ice cover is present and, therefore could increase as surface-ice cover decreases.

Reduced late-summer hypolimnion oxygen levels are likely related to earlier lake ice-out dates (discussed by Stewart (1976) for some lakes in Madison, Wisconsin). Earlier ice-outs could affect the productivity and abundance of phytoplankton (Maeda and Ichimura, 1973) and organisms at higher trophic levels (Porter and others, 1996).

\section{Framework for a Hydrologic Climate- Response Program}

The framework of the hydrologic climate-response program presented here consists of four major parts: (1) identifying homogeneous climate-response regions; (2) identifying hydrologic components, key variables of those components, and data-collection sites that would be included in a hydrologic climate-response data network; (3) regularly updating historical trends of hydrologic network variables; and (4) establishing basins for process-based studies.

\section{Climate-Response Regions}

Hydrologic climate-response regions should have relatively homogeneous climates. Maine's climate, as described in the Introduction section, is complex, with a large north-to-south gradient, coastal-to-inland gradient,

Table 1. Hydrologic climate-response regions in Maine.

\begin{tabular}{cl}
\hline $\begin{array}{c}\text { Region } \\
\text { number }\end{array}$ & \multicolumn{1}{c}{ River basins included } \\
\hline 1 & Southern coastal, Saco, Presumpscot, mid-coastal \\
2 & Eastern coastal (Downeast) \\
3 & Lower Androscoggin, lower Kennebec \\
4 & Lower Penobscot, St. Croix \\
5 & Upper Androscoggin, upper Kennebec, upper Penobscot \\
6 & Upper St. John, Allagash \\
7 & Lower St. John, Fish, Aroostook, Meduxnekeag \\
\hline
\end{tabular}

and sea-level-to-mountain-region gradient. Maine would be divided into seven regions (fig. 4, table 1) that follow major river-basin boundaries, have relatively homogeneous climates, and are broadly consistent with the U.S. Environmental Protection Agency ecoregions (U.S. Environmental Protection Agency, 2007) and biophysical regions of Maine as defined by Krohn and others (1999). Major river-basin boundaries would be followed by subdividing basins to hydrologic units with 8-digit codes (Seaber and others, 1987) or larger. Results of additional analyses of hydrologic variations may indicate a need to change the boundaries and (or) number of hydrologic climate-response regions in the future. It may also be necessary to divide regions on a scale finer than major river-basin boundaries, particularly in region 1 where coastal and mountainous areas are included in the same hydrologic unit.

\section{Hydrologic Climate-Response Data Network}

An important part of developing a USGS hydrologic climate-response program in Maine is the establishment of a hydrologic climate-response data network, including the identification of hydrologic components, key variables of those components, and data-collection sites. As an example, streamflow has been identified as a primary component, with a key variable of streamflow being winter-spring streamflow timing. The key variables of components discussed in this section have been demonstrated or are expected to be responsive to climate change in the next few decades and are important for human water use or ecosystem function.

Two criteria were used to identify key variables to be included in a hydrologic climate-response data network: the existence of long-term historical data and the human or ecological importance of the component variables. Longterm historical data allow a much better perspective on future climate-related changes than short-term data because past decadal variability and longer term changes are better known. The Introduction section of this report lists known historical changes for variables of several hydrologic components and their known importance for humans and ecosystems. There are many variables to describe some of the components in a hydrologic climate-response data network. For example, streamflow variables could include annual peak flows, March mean flows, or many other measures. On the basis of extensive past work, some variables are more likely than others to be responsive to past and future climate changes (see Introduction section). Components proposed for inclusion in a hydrologic climate-response data network have at least one key variable with extensive historical data at multiple sites: streamflow, lake ice, river ice, snowpack, and groundwater. Other hydrologic components are important to humans and (or) ecosystems but lack variables with extensive historical data. Key variables of primary components are listed in the following sections; additional variables could be added as part of a larger program. 


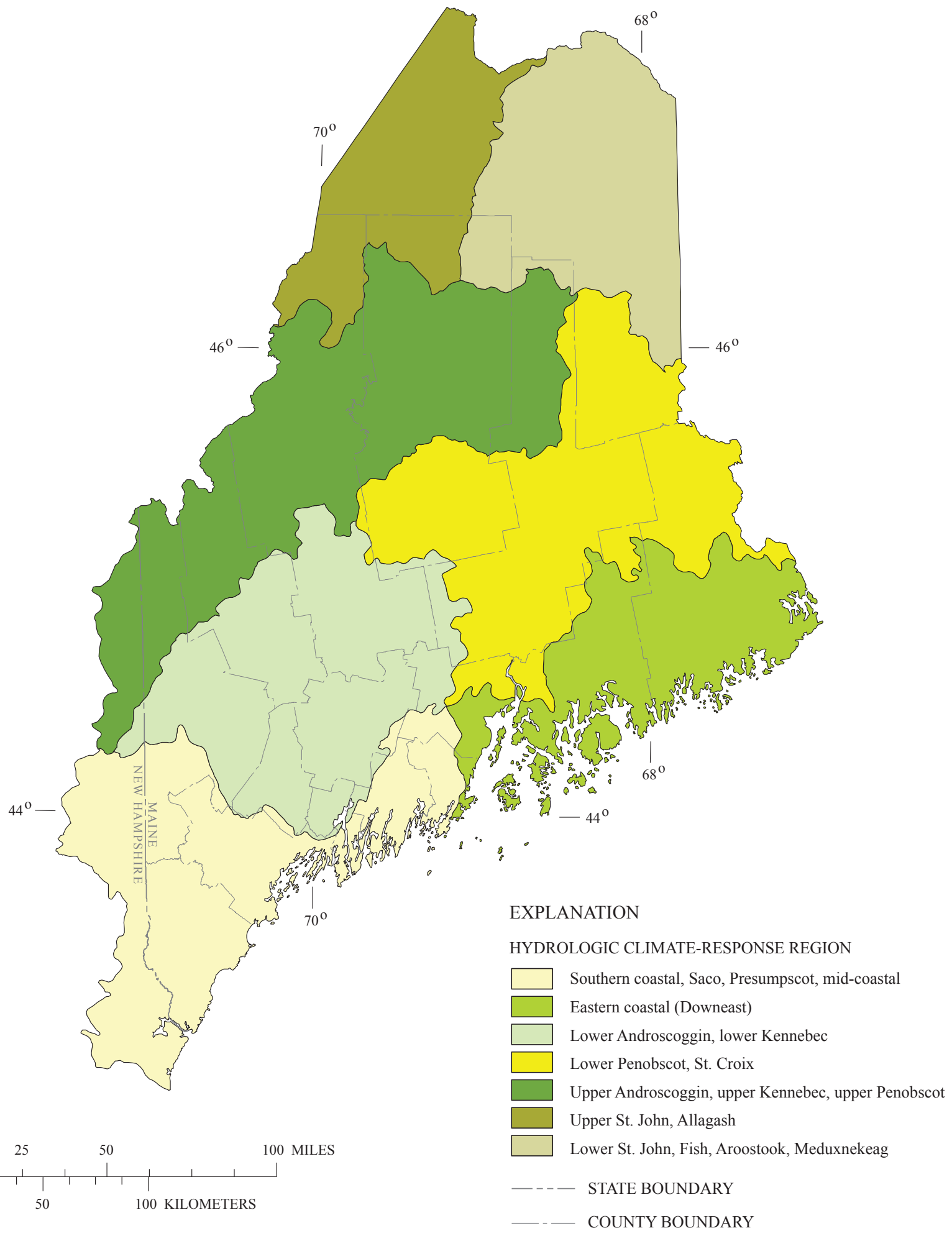

Base from U.S. Geological Survey digital files, Universal Transverse Mercator projection, Zone 19

Figure 4. Location of hydrologic climate-response regions in Maine. 


\section{Primary Components and Associated Key Variables}

\section{Streamflow}

For the streamflow component, two key variables are proposed: winter-spring streamflow timing and the magnitude of the annual peak flow. Winter-spring streamflow timing is measured by the winter-spring center-of-volume (WSCV) date (Dudley and Hodgkins, 2002; Hodgkins and others, 2003b; Hodgkins and Dudley, 2006b). The WSCV is a robust measure of streamflow timing. To compute the WSCV date, daily flow volumes from the start to the end of the annual winter-spring season are summed. The WSCV date is then computed as the date, from the start of the season, by which half of the volume flows by a gaging station. Another key variable derived from streamflow data - the magnitude of summer base flows - is discussed in the Groundwater section.

The USGS has been measuring and recording daily streamflow at some sites in Maine for more than a century. More than 50 years of USGS streamflow data are available for many rural, unregulated streams (http://waterdata.usgs.gov/ $u s a / n w i s / s w$ ). The streamflow data at these sites have been collected by the USGS using consistent, well-documented, high-quality methods (Corbett and others, 1943; Rantz and others, 1982). Therefore, historical changes in the data can be determined with confidence.

A network of streamflow-gaging stations whose basins are relatively free of human influences such as regulation, diversion, land-use change, or extreme groundwater pumpage was defined by Slack and Landwehr (1992). This HydroClimatic Data Network (HCDN) includes data from more than 1,500 streamflow-gaging stations across the United States. Hodgkins and others (2003b) used all HCDN stations in Maine with daily streamflows free of substantial human influences and at least 50 continuous years of record through 2000 to examine changes over time in the timing of winterspring and fall high streamflows. Fourteen streamflow-gaging stations in Maine met the criteria of that study (table 2, fig. 5). The two stations in New Hampshire are on rivers that flow into Maine. These 14 stations would be the starting point for stations to be included in the streamflow component of a hydrologic climate-response data network in Maine.

Regulation at each of these stations was analyzed further because low flows can be sensitive to even minor regulation (Hodgkins and others, 2005b). The amount of regulation upstream from each U.S. Geological Survey gaging station is listed in the annual USGS Water-Data Reports for Maine and in their predecessor USGS Water-Supply Papers. If a river

Table 2. Long-term streamflow-gaging stations on Maine rivers that drain relatively natural basins.

[USGS, U.S. Geological Survey]

\begin{tabular}{cclc}
\hline $\begin{array}{c}\text { Sequential } \\
\text { number }\end{array}$ & $\begin{array}{c}\text { USGS streamflow-gaging } \\
\text { station number }\end{array}$ & \multicolumn{1}{c}{ USGS streamflow-gaging station name } & Period of streamflow record \\
\hline 1 & 01010000 & St. John River at Ninemile Bridge, Maine & $1950-2007$ \\
2 & 01010500 & St. John River at Dickey, Maine & $1910-1911,1946-2007$ \\
3 & 01013500 & Fish River near Fort Kent, Maine & $1903-1908,1911,1929-2007$ \\
4 & 01014000 & St. John River below Fish River at Fort Kent, Maine & $1926-2007$ \\
5 & 01022500 & Narraguagus River at Cherryfield, Maine ${ }^{1}$ & $1948-2007$ \\
6 & 01030500 & Mattawamkeag River near Mattawamkeag, Maine & $1934-2007$ \\
7 & 01031500 & Piscataquis River near Dover-Foxcroft, Maine ${ }^{2}$ & $1902-2007$ \\
8 & 01038000 & Sheepscot River at North Whitefield, Maine & $1938-2007$ \\
10 & 01047000 & Carrabassett River near North Anson, Maine & $1902-1907,1925-2007$ \\
11 & 01052500 & Diamond River near Wentworth Location, New Hampshire & $1941-2007$ \\
12 & 01055000 & Swift River near Roxbury, Maine & $1929-2007$ \\
13 & 01057000 & Little Androscoggin River near South Paris, Maine & $1913-1924,1931-2007$ \\
14 & 01060000 & Royal River at Yarmouth, Maine & $1949-2004$
\end{tabular}

\footnotetext{
${ }^{1}$ Unusual regulation affected flows September 2-6, 1978, and September 22-26, 1985.
}

${ }^{2}$ Data from this station inappropriate for analysis of historical low-flow changes because of historical regulation.

${ }^{3}$ Data from this station for years prior to 1931 inappropriate for analysis of historical low-flow changes because of historical regulation.

${ }^{4}$ Data from this station for years prior to 1932 inappropriate for analysis of historical low-flow changes because of historical regulation.

${ }^{5}$ Unusual regulation affected flows July 23-25, 1980 


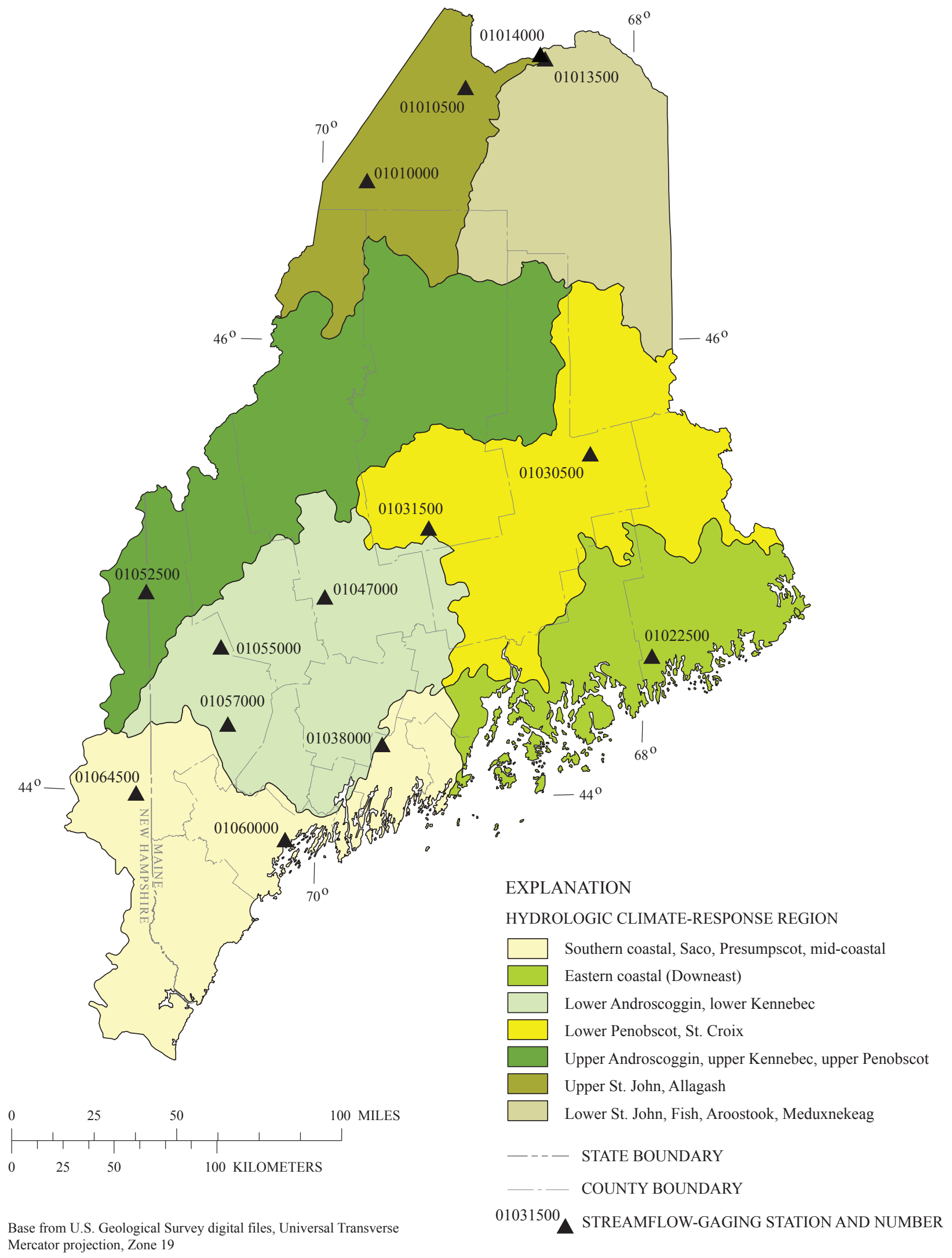

Figure 5. Location of long-term streamflow-gaging stations that drain relatively natural basins in and near Maine. 
was noted in the USGS reports as having low-flow regulation or significant storage regulation, low flows from those years are not considered appropriate for inclusion in analyses of historical climate-related trends. If a river was noted as having some, infrequent, or diurnal low-flow regulation, the flows are considered appropriate. Plots of low flows over the period of record at all sites were used to verify the qualitative regulation criteria. Based on these regulation criteria, data from one station (Piscataquis River) should not be analyzed for low flows, and early years of data at two stations (Carrabassett and Little Androscoggin Rivers) are not appropriate for inclusion in low flow analyses, nor are data for a few days with unusual regulation at two stations (Narraguagus and Royal Rivers) (table 2).

\section{Lake Ice}

The key (and only commonly available) historical measure of lake ice is lake ice-out date - the annual date in spring when winter ice cover leaves a lake (Hodgkins and others, 2002). In Northern Hemisphere mid-latitude areas such as Maine, ice-out dates can serve as useful indicators of late winter and early spring climate change. A remarkable amount of lake ice-out data has been recorded and saved in Maine over the past two centuries. Lake ice-out dates for 23 lakes in Maine were compiled (Hodgkins and James, 2002) and analyzed (Hodgkins and others, 2002) (table 3, fig. 6). As of 2008, 5 lakes have more than 160 years of data and 15 have more than 100 years of data. Long-term lake ice-out data for many lakes in Maine represent a unique hydroclimatic data set that is very useful for continued monitoring of hydrologic response to regional climate change. These lakes would be the starting point for lakes used in a hydrologic climate-response data network.

Most of the lakes in this study are in rural areas (Hodgkins and others, 2002). Lakes in northern Maine generally drain remote, undeveloped forests. Lakes in southern Maine generally drain rural areas with forests, some low-density residential development, and small towns. Lake Auburn is near a relatively small urban area. The ice-out dates for this lake could be affected by urban heat-island temperature effects. It is unlikely that any activities that would affect the trends in iceout dates over time, such as warm-water discharges, occurred on the rural lakes in this study or on their inlet streams.

Ice-out definitions for individual lakes can vary over time and among observers. (Hodgkins and others, 2002). Twenty years or more of overlapping data from independent observers were available for six lakes. Based on this limited data set, Hodgkins and others (2002) concluded that observer biases (different people on the same lake recording different ice-out dates for the same year) of more than 1 day are unlikely on relatively round lakes. In contrast, 3- to 4-day biases appear likely on long, narrow lakes if the observation locations are on opposite ends of the lake. On two long, narrow lakes with north-south axes, the observer with later ice-out dates was located at the northern end of the lakes. These observational biases could result in large biases in ice-out trends over time at individual lakes. At a large number of lakes, however, it is unlikely that observer-location biases would tend to bias trend tests in any one direction. For example, for a large number of lakes there is no reason to expect that people observed older ice-outs at the southern end of lakes and observed more recent ice-outs at the northern end of lakes.

\section{River Ice}

\section{Occurrence}

For river-ice occurrence, key variables are the annual first day of ice-affected flow in the winter, the last day of iceaffected flow in the spring, and the total number of days of ice-affected flow. The primary product of USGS streamflowgaging efforts has been the computation and publication of daily mean river flows. Flows, however, are not typically

Table 3. Maine lakes with long-term ice-out data.

\begin{tabular}{|c|c|c|c|}
\hline $\begin{array}{l}\text { Lake } \\
\text { number }\end{array}$ & Lake name & $\begin{array}{l}\text { Period of } \\
\text { record }\end{array}$ & $\begin{array}{l}\text { Years of } \\
\text { record }\end{array}$ \\
\hline 1 & Eagle & 1922-2008 & 75 \\
\hline 2 & Portage & $1925-2008$ & 83 \\
\hline 3 & Squa Pan & $1930-2008$ & 70 \\
\hline 4 & Moosehead & $1848-2008$ & 161 \\
\hline 5 & Aziscohos & $1913-2008$ & 94 \\
\hline 6 & Rangeley & $1880-2008$ & 129 \\
\hline 7 & Mooselookmeguntic & $1884-2008$ & 107 \\
\hline 8 & Richardson & $1880-2008$ & 127 \\
\hline 9 & Umbagog & $1880-2008$ & 118 \\
\hline 10 & West Grand & 1878-2008 & 131 \\
\hline 11 & Sebec & 1879-2008 & 128 \\
\hline 12 & Embden & $1925-2005$ & 80 \\
\hline 13 & Pennesseewassee & $1874-2008$ & 133 \\
\hline 14 & Kezar & $1901-2008$ & 107 \\
\hline 15 & Swan & 1891-2008 & 118 \\
\hline 16 & Messalonskee & 1909-2008 & 75 \\
\hline 17 & China & $1874-2008$ & 82 \\
\hline 18 & Maranacook & $1925-2008$ & 84 \\
\hline 19 & Cobbosseecontee & $1840-2008$ & 167 \\
\hline 20 & Damariscotta & $1837-2008$ & 171 \\
\hline 21 & Auburn & $1836-2008$ & 166 \\
\hline 22 & Thompson & $1902-2008$ & 102 \\
\hline 23 & Sebago & $1807-2008$ & 168 \\
\hline
\end{tabular}




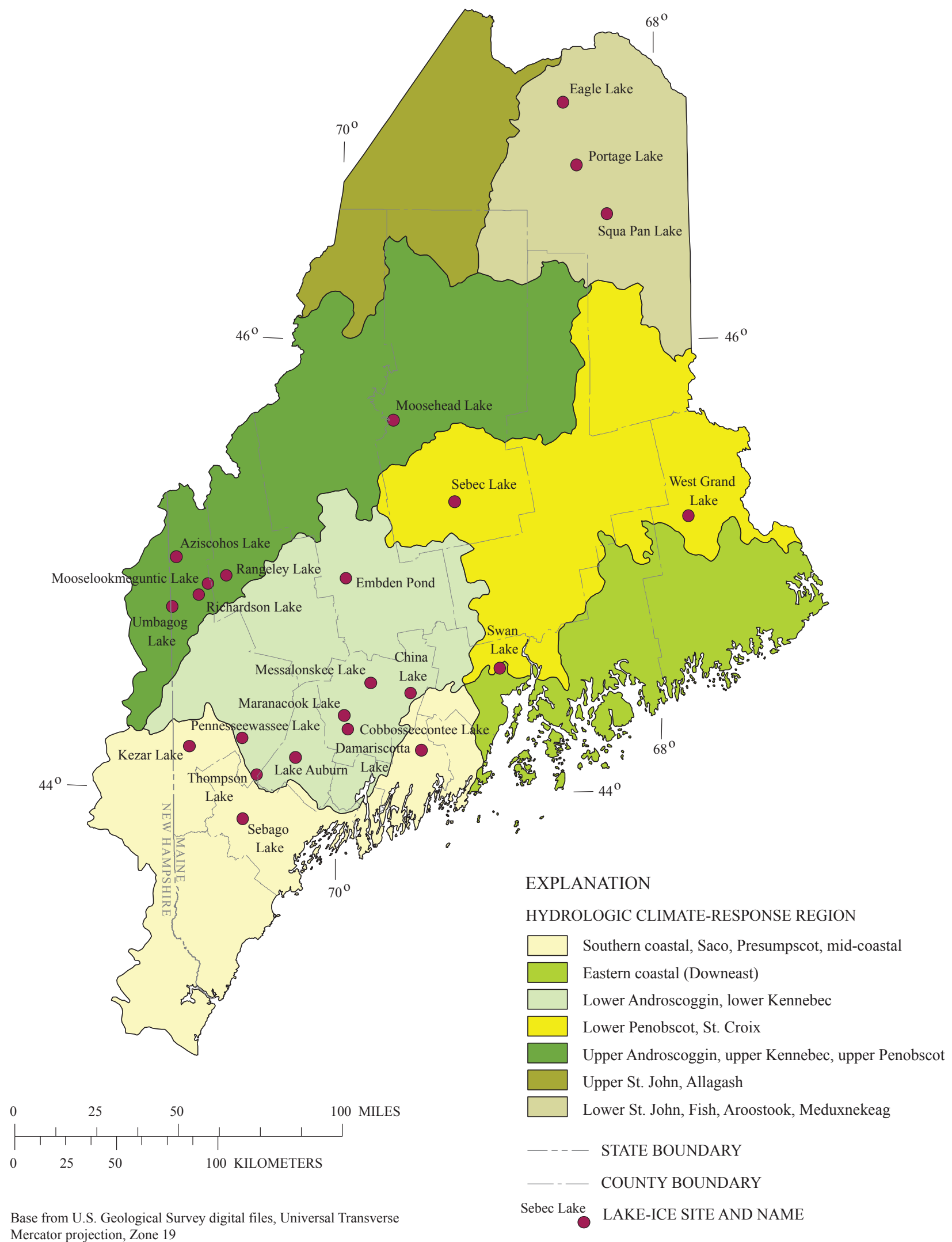

Figure 6. Location of lakes with long-term ice-out data in Maine. 
measured continuously. Instead, the river height is measured continuously (currently once every 15 minutes) and the flows computed with a river height/flow relation, called a rating curve. The presence of ice in a river channel affects the relation between river height and flow (Rantz and others, 1982); therefore, the presence of ice in rivers has been historically determined and recorded.

Records from all gaging stations on rivers in Maine were searched for long-term, usable records of the occurrence of ice-affected flow. Long-term records were defined as those from a gaging station that was operated for at least 50 years with records through 2000 (Hodgkins and others, 2005a). Usable records were defined as those from a gaging station whose hydraulic-control-section location (typically, the riffles downstream from a gaging station that control the river height at the station at low to medium flows) did not change during the period of record and whose flows were not subject to substantial regulation or urbanization. Ice conditions can differ substantially with location, even over short distances upstream or downstream from any given location. For this reason, rivers on which the control-section location changed over the period of record were not used. Substantial regulation was defined as regulation that could affect the formation and (or) stability of ice at the station. This required that a river at a gaging station had either no known flow regulation over time or only low-flow regulation, of an amount that was judged to be insignificant.

The formation of ice in river channels, in particular on hydraulic-control sections, affects the river height/flow relation by causing backwater (a higher than normal river height for a given flow) (Rantz and others, 1982). This backwater varies with the quantity and nature of the ice, as well as with the flow. Backwater at a gaging station can be caused by anchor ice or by surface ice. Anchor ice is an accumulation of frazil (slush) ice that adheres to the rocks of a river bed. It may build up on the river bed and (or) the hydraulic control section to the extent that backwater occurs. Surface ice normally forms first along the edges of a river and then builds out from the shore, eventually forming an ice sheet across the entire river. Surface ice, where it is in contact with the river, increases the frictional resistance to the river flow and the river height will increase for a given flow.

Rises in river height due to anchor ice are clearly recognizable from continuous river-height records (Hodgkins and others, 2005a). Rises in river height due to surface ice are often recognizable from continuous river-height records. River-height records are supplemented by visual observations of river-ice conditions, river-flow measurements, daily temperature and precipitation records, and flows from nearby gages to determine days of ice-affected flow. River-height rises, particularly rises that lack the smoothness of those caused by an increase in flow, combined with very cold temperatures and a lack of precipitation are indicative of ice-affected river flow.

The first ice-affected river flows in Maine each fall are caused by the first substantial presence of anchor ice and (or) surface ice (Hodgkins and others, 2005a). The breakup of river ice in the spring, at rivers with complete or nearly complete ice cover, typically is a dramatic event in which the ice is picked up and transported by medium or high river flows. Dynamic river-ice breakup can also occur in the winter. Days of ice-affected flow each winter, in general, are continuous or nearly continuous in northern Maine and can be less continuous in southern and coastal Maine. It is unlikely that any activities, such as warm-water discharges, that would affect the trends in ice-affected river flows over time occurred on or near the rivers or on their tributaries.

Eleven gaging stations on rivers in Maine met the criteria in Hodgkins and others (2005a) (table 4, fig. 7). These stations would be the starting point for river-ice data collection for a hydrologic climate-response data network.

Table 4. Maine rivers with long-term ice occurrence data.

[USGS, U.S. Geological Survey]

\begin{tabular}{cll}
\hline $\begin{array}{c}\text { USGS streamflow-gaging } \\
\text { station number }\end{array}$ & \multicolumn{1}{c}{ USGS streamflow-gaging station name } & \multicolumn{1}{c}{ Period of record } \\
\hline 01011000 & Allagash River near Allagash, Maine & $1932-2007$ \\
01013500 & Fish River near Fort Kent, Maine & $1930-2007$ \\
01014000 & St. John River below Fish River at Fort Kent, Maine & $1934-2007$ \\
01022500 & Narraguagus River at Cherryfield, Maine & $1949-2007$ \\
01031500 & Piscataquis River near Dover-Foxcroft, Maine & $1931-2007$ \\
01038000 & Sheepscot River at North Whitefield, Maine & $1939-2007$ \\
01048000 & Sandy River near Mercer, Maine & $1929-1979,1988-2007$ \\
01052500 & Diamond River near Wentworth Location, New Hampshire & $1942-2007$ \\
01055000 & Swift River near Roxbury, Maine & $1931-2007$ \\
01060000 & Royal River at Yarmouth, Maine & $1950-2004$ \\
01064500 & Saco River near Conway, New Hampshire & $1930-2007$ \\
\hline
\end{tabular}




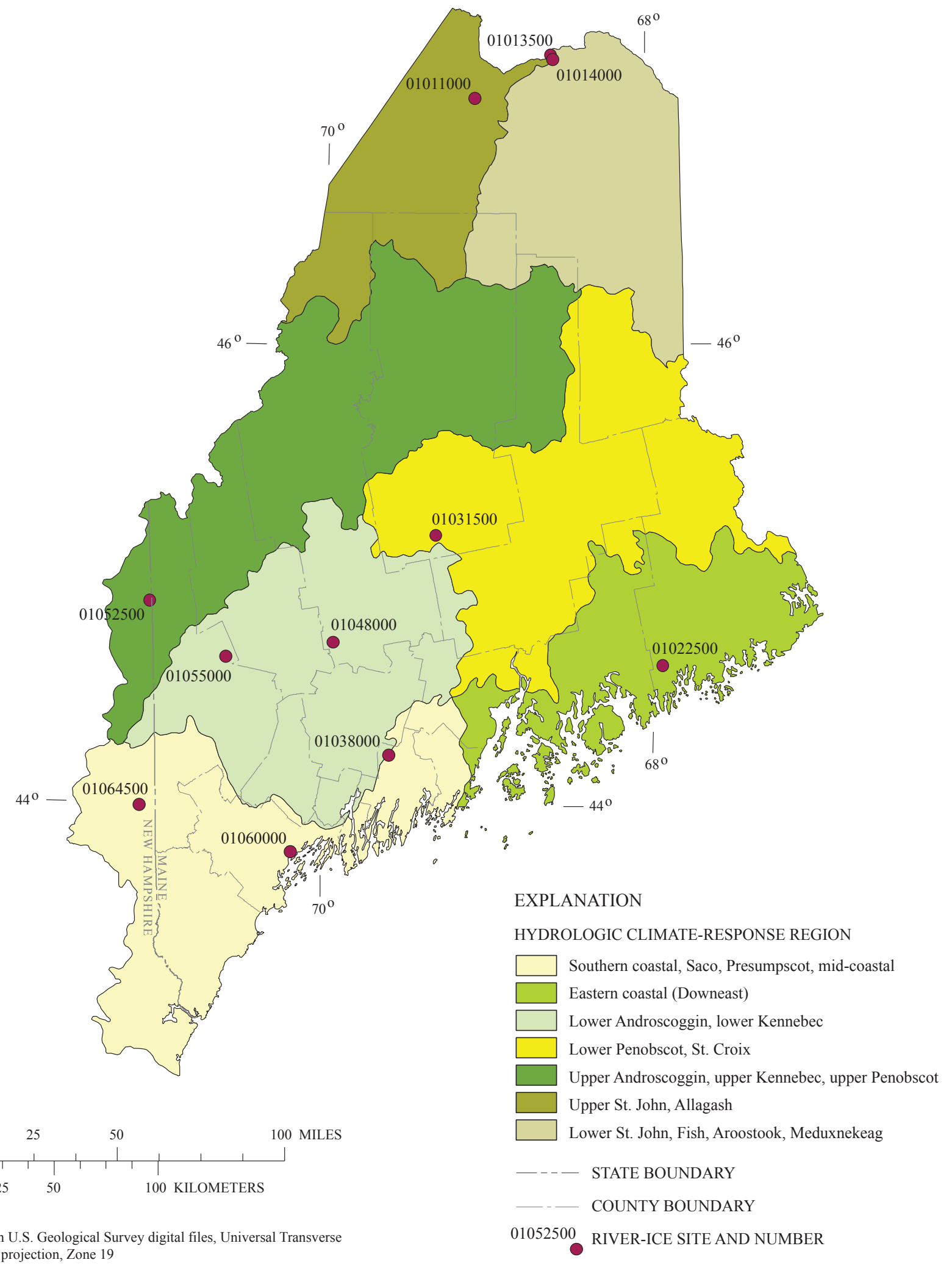

Figure 7. Location of rivers with long-term ice-occurrence data in and near Maine. 
The presence of ice in rivers has been determined by the USGS using the same methods since 1913 (and probably for several years previously) to the present (Hoyt, 1913; Rantz and others, 1982), with one known exception. The earliest river-height records in New England typically were collected daily by an observer, rather than by a continuous recorder, until the 1930s (Hodgkins and others, 2005a). The presence of ice, especially anchor ice, that affected the river height/flow relation may have been interpreted differently using these two methods of data collection. Therefore, only years in which continuous recorders were used at each gaging station are considered appropriate for use in river-ice analyses (table 4).

The determination of days of ice-affected flow that occur during periods of missing river-height record at a gaging station can be less accurate than that for periods when these records are available (Hodgkins and others, 2005a). This is because estimates during periods of missing river-height records are based on flows from nearby rivers and on daily temperature and precipitation records. Individual years of record at gaging stations with missing winter river-height records were censored if there was any question about the accuracy of the ice-affected-flow records (Hodgkins and others, 2003a). On average, 4 years of data were censored at each station.

\section{Thickness}

Annual river-ice thickness for set winter dates (such as February 28th) is a key variable of river ice. USGS winter streamflow measurements allow for the historical estimation of river-ice thickness at streamflow-gaging stations, as has been done for the Piscataquis River in Maine (Huntington and others, 2003). Rivers should be free of substantial human influence, as described in the preceding Occurrence section, and streamflow-measurement locations should be constant over time, as ice conditions can vary dramatically upstream or downstream from a location. Another consideration in river selection is that frazil (slush) ice should not be present underneath solid ice because the two types of ice historically have not been differentiated when making winter streamflow measurements.

To measure streamflow under ice in winter, holes are drilled through the ice to reach the underlying water (Rantz and others, 1982). A standard part of USGS winter measurements has been to measure the distance from the water surface to the bottom of the ice (WSBI), which has been done with consistent methods over time. WSBI is different from ice thickness because the water surface can be above or below the top of the ice; however, it is highly correlated with ice thickness (Huntington and others, 2003). Actual ice-thickness measurements at sites can therefore be estimated by regression methods if the relation between WSBI and ice thickness is strong and linear, as it was for the Piscataquis River $(\mathrm{r}=0.95)$. USGS streamflow-gaging stations in Maine with long-term records would be analyzed for the criteria described above, and appropriate stations would become part of a hydrologic climate-response data network.

\section{Snowpack}

Key snowpack variables are the magnitude of late-winter water equivalent, depth, and density for selected dates. Emergency management and response agencies, flood-forecasting agencies, people who live near streams, and many waterdependent industries need to know how much water to expect each year from snowmelt. Primarily for this reason, the Maine Cooperative Snow Survey Program, run jointly by the Maine Geological Survey (MGS) and the USGS, compiles snowpack data collected by the USGS, the MGS, the National Weather Service, electric-power utilities, water-power companies, pulp and paper companies, and others on a regular basis (currently weekly, historically biweekly) in late-winter and spring (Hodgkins and Dudley, 2006a).

The depth and water equivalent (the depth of water that would result if the snowpack were melted) of the snowpack have been measured at selected sites in Maine since the early part of the 20th century (Hodgkins and others, 2005c). Most of the sites are in flat or gently sloping areas of mixed hardwood and conifer forest. Measurements are not made near conifers. Most data are collected at locations with an elevation of less than 2,000 ft. Historical site information for the sites in this report is extremely limited. Some sites have been moved away from the local effects of development, extensive logging, or unacceptable amounts of conifer growth.

Snowpack depth and water-equivalent data were analyzed for those sites with data spanning at least 50 years through 2004 (Hodgkins and Dudley, 2006a). The exact date of sampling at a site varies from year to year. Data for a site commonly are not available for every year for a given sampling window. Sampling windows were defined as 15-day windows centered on February 15, March 1, March 15, April 1, April 15, and May 1. To be included for analysis, the sites were required to have at least 50-percent complete data for the first and second halves of their record for at least one sampling window. Thirty-seven sites in and near Maine met the described criteria. Historical snow depth and water-equivalent data for these sites are reported in Hodgkins and others (2005c).

Because sampling windows were used, it is possible to have biased sampling over time at sites (Hodgkins and Dudley, 2006a). If sampling tends to be earlier or later over time, any significant trends in the snowpack data could be the result of sampling bias. All data sets (individual sites for each applicable sampling window) that met the criteria for inclusion were tested for significant changes over time in the date of sampling. Data from many sites sampled during the March 1 sampling window were found to be biased, with many sampling dates prior to March 1 early in the record and many dates after March 1 later in the record. Fourteen sites were eliminated because of significant bias in the date of sampling. Data from 23 sites with data for at least one sampling window did not show significant sampling bias and were considered appropriate for use in computing climate-related trends over time (table 5, fig. 8). These sites would be the starting point for sites to be included in a hydrologic climate-response data network. 
Table 5. Long-term snowpack sites in and near Maine.

[Abbreviations in site name are part of the official name. All sites are in Maine, unless otherwise noted. A sampling window is defined as a 15-day period centered on the date shown.]

\begin{tabular}{|c|c|c|}
\hline $\begin{array}{c}\text { Site } \\
\text { number }\end{array}$ & Site name & $\begin{array}{c}\text { Sampling } \\
\text { window }\end{array}$ \\
\hline 1002 & The Forks & March 1 \\
\hline 1004 & Grindstone & March 1 \\
\hline 1015 & Mercer & March 1 \\
\hline 1020 & Dover-Foxcroft (B) & March 1 \\
\hline 1024 & North Anson & March 1 \\
\hline 1044 & Pinkham Notch (UWP), N.H. & March 1 \\
\hline 1050 & Pittsfield (B) & March 1 \\
\hline 1053 & Gorham, N.H. & March 1 \\
\hline 1066 & Mayfield (Bingham Upper) & March 1 \\
\hline 1292 & Kokadjo (KWP) & March 1 \\
\hline 1002 & The Forks & March 15 \\
\hline 1018 & Amherst (BH) & March 15 \\
\hline 1022 & Fort Kent & March 15 \\
\hline 1024 & North Anson & March 15 \\
\hline 1027 & Errol/Errol Dam (UWP), N.H. & March 15 \\
\hline 1028 & Aziscohos/Aziscohos Dam (UWP) & March 15 \\
\hline 1030 & Middle Dam (UWP) & March 15 \\
\hline 1031 & Upper Dam (UWP) & March 15 \\
\hline 1046 & South Paris & March 15 \\
\hline 1061 & Guerrette & March 15 \\
\hline 1100 & Eustis (KWP) & March 15 \\
\hline 1246 & Stratton (KWP) & March 15 \\
\hline 1288 & Carrabassett (KWP) & March 15 \\
\hline 1289 & Dallas (KWP) & March 15 \\
\hline 1290 & Chain of Ponds (KWP) & March 15 \\
\hline 1027 & Errol/Errol Dam (UWP), N.H. & April 1 \\
\hline 1028 & Aziscohos/Aziscohos Dam (UWP) & April 1 \\
\hline 1030 & Middle Dam (UWP) & April 1 \\
\hline 1031 & Upper Dam (UWP) & April 1 \\
\hline
\end{tabular}

\section{Groundwater}

Key variables for the groundwater component are the amount of winter recharge and the amount of spring recharge, as measured by groundwater levels, and the base-flow component of summer streamflows. The USGS has collected groundwater-level data in Maine for several decades but no long-term trend analyses of groundwater data in Maine have been completed. The groundwater network would be examined for relatively complete long-term data at wells that have not been moved or have other changes that may make comparisons between older and newer data inappropriate. The most appropriate sites would be identified for inclusion in a hydrologic climate-response data network. Given the relatively low density of groundwater-monitoring wells in Maine, it may be necessary to add wells to the network.

The base-flow component of streamflow comes from groundwater and other delayed sources. The USGS streamflow-gaging stations identified for potential inclusion in a hydrologic climate-response data network and appropriate for the analysis of low flows (table 2) would be appropriate to use as input to an automated base-flow-separation technique, such as HYSEP (Sloto and Crouse, 1996), to separate base flow from total streamflow.

\section{Secondary Components}

To design a more comprehensive hydrologic climateresponse data network, secondary components would be added. In general, these would be hydrologic components for which historical data are limited. Components could include streamflow temperature, dissolved-oxygen concentration, and other water-quality parameters. They could also include components representing parts of the water cycle, such as evapotranspiration, that historically have not been measured at many sites.

\section{Existing Primary and Secondary Data-Collection Sites}

Within each climate-response region, for each key variable, the most appropriate data-collection sites would be identified. The starting point for sites would be those with long-term, high-quality data that were identified earlier in this report. Primary sites would then be identified that are representative of the region and are important for other reasonssuch as relevance to endangered species like Atlantic salmon, proximity to Native American interests (fig. 9) and U.S.

Department of Interior and Agriculture lands (fig. 10), and (or) importance for water supply. The surface-water sources in Maine with the largest withdrawals are shown in figure 11. Secondary sites within each hydrologic region would be identified as the long-term, high-quality sites that are in excess of the minimum number of sites needed.

\section{New Data-Collection Sites}

Some regions do not contain sites with long-term historical data for some key hydrologic variables. In these cases, sites with less historical data would be considered. If no appropriate sites are found, data collection at new sites would be started. 


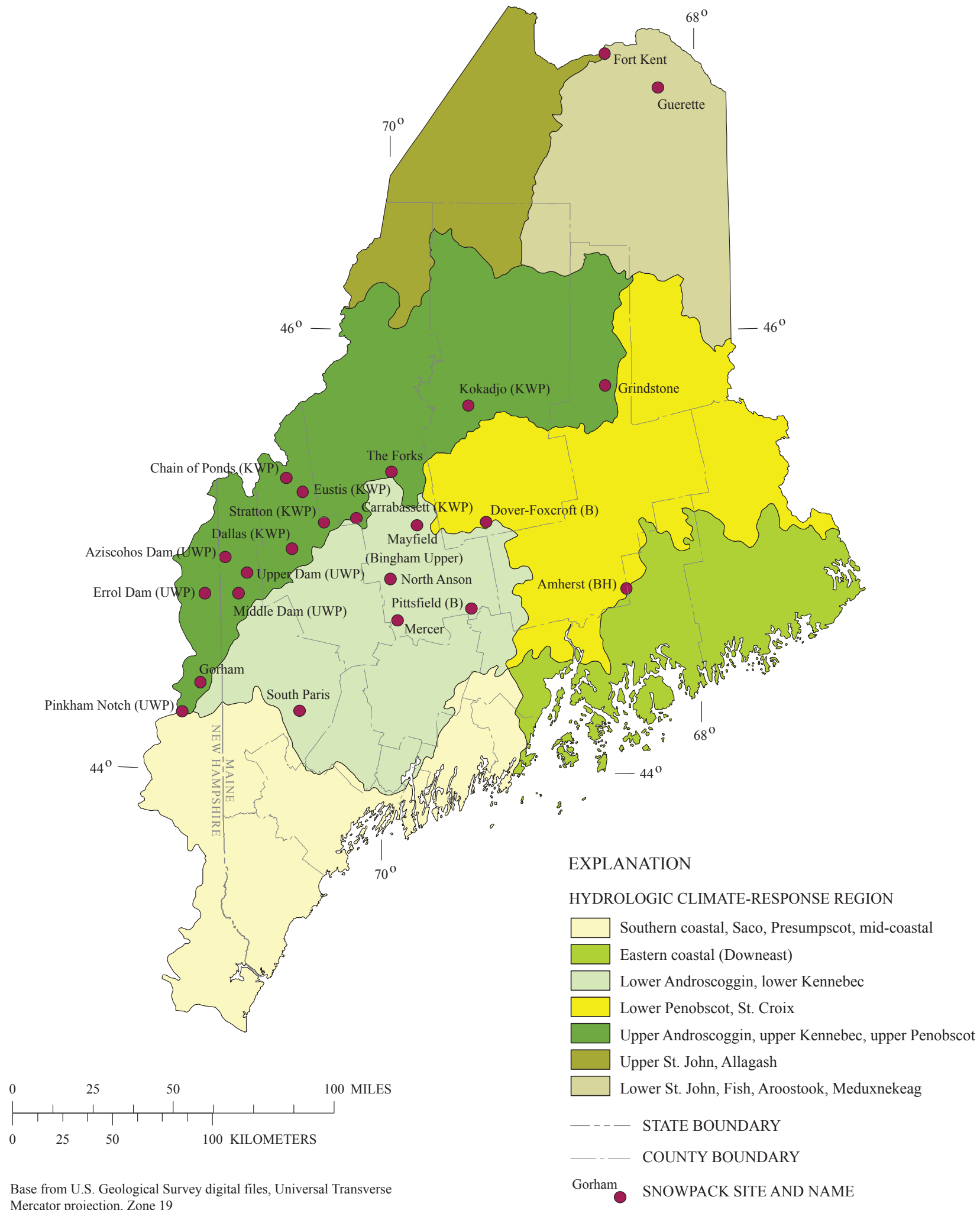

Figure 8. Location of long-term snowpack sites in and near Maine. 


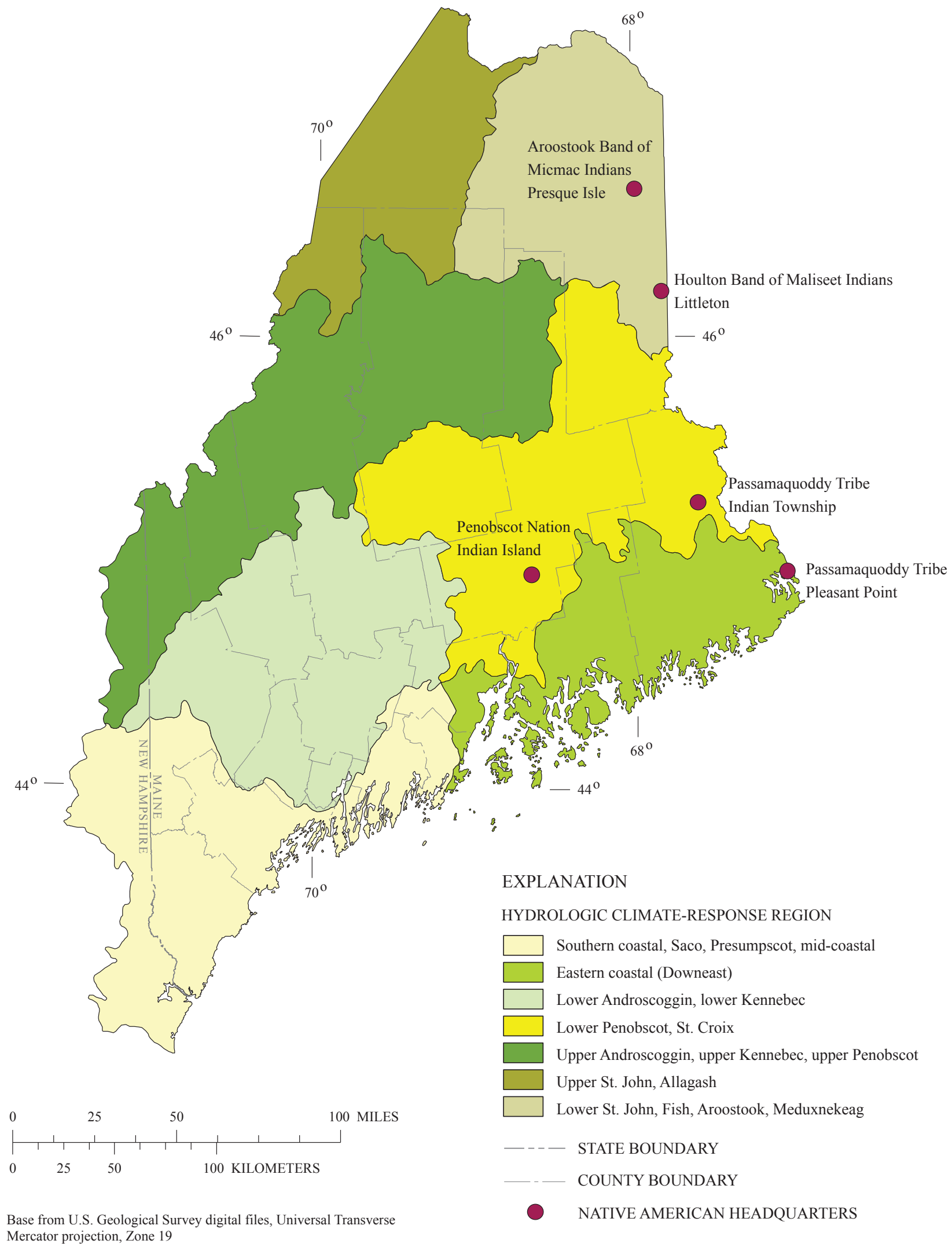

Figure 9. Location of Native American headquarters in Maine. 


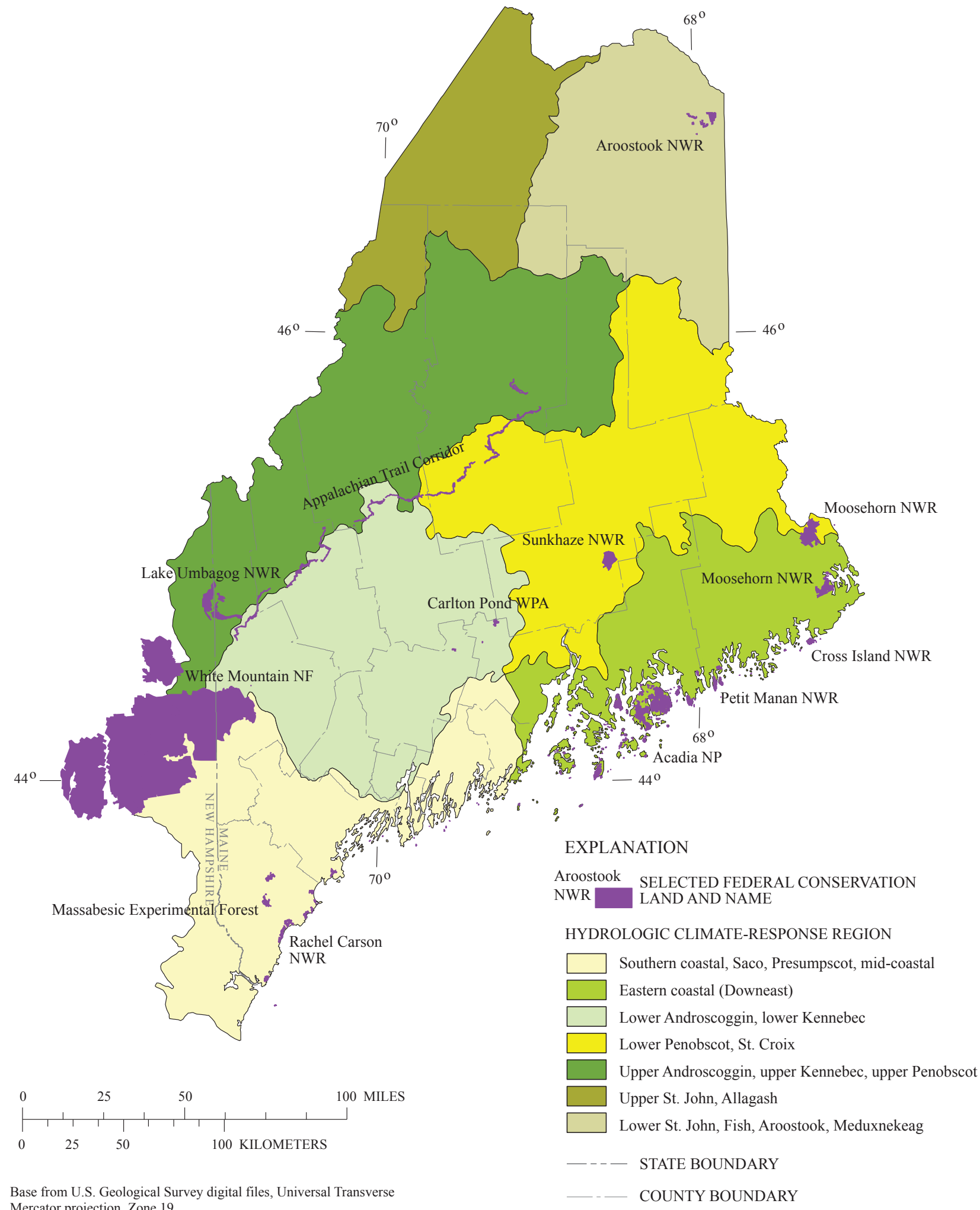

Figure 10. Location of U.S. Department of Interior and Agriculture lands in and near Maine. 


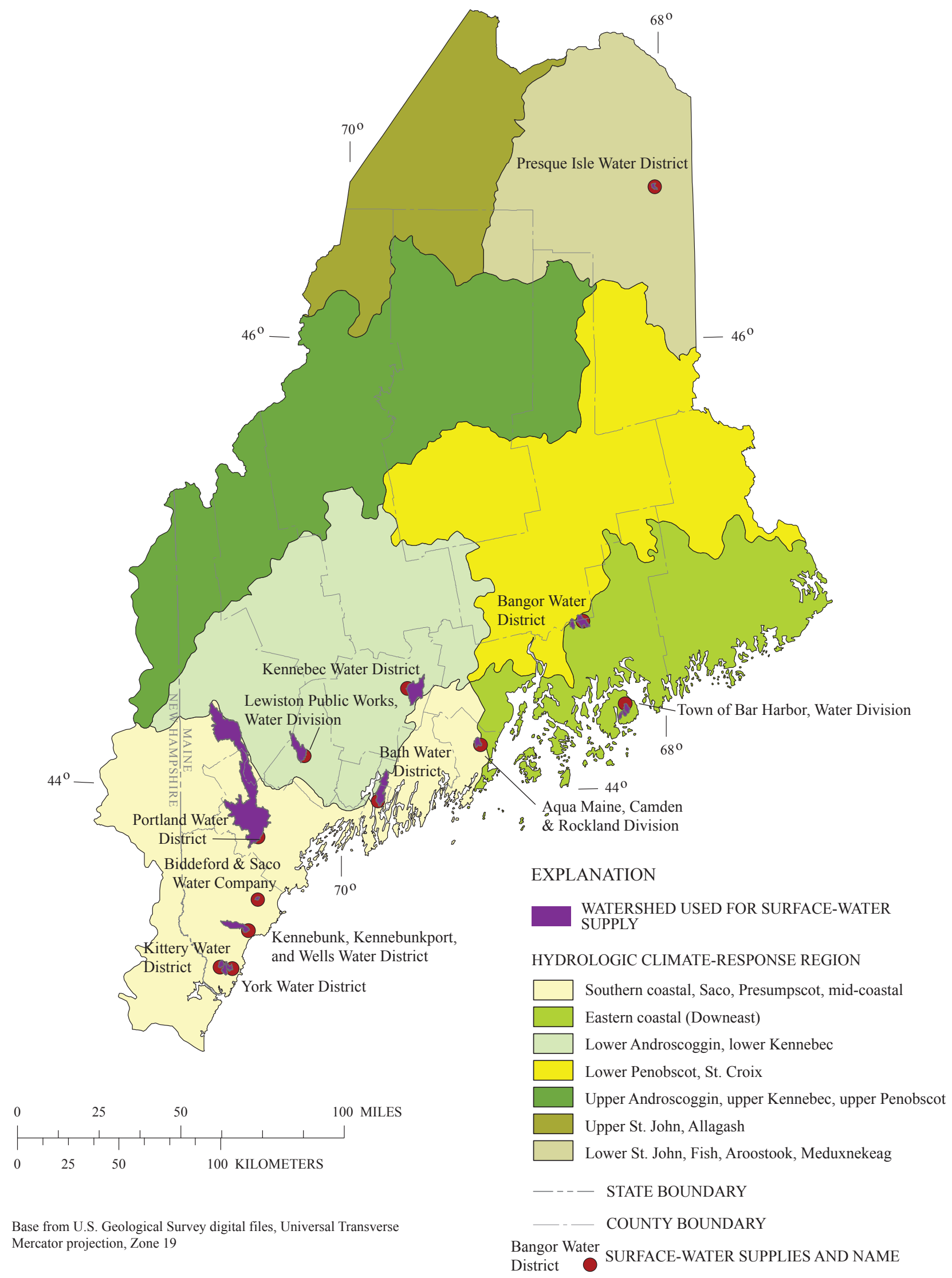

Figure 11. Location of major surface water suppliers in Maine. 
Table 6. Examples of annual cycles of trend updates for key variables of hydrologic components.

[-- indicates no planned trend updates]

\begin{tabular}{lcc}
\hline \multicolumn{1}{c}{ Primary component and key variables to be included in trend updates } & $\begin{array}{c}\text { Lower intensity effort } \\
\text { (one variable per year) }\end{array}$ & $\begin{array}{c}\text { Higher intensity effort } \\
\text { (three variables per year) }\end{array}$ \\
\hline Streamflow - timing of winter-spring flows & Year 1 & Year 1 \\
Streamflow - magnitude of annual peak flow & Year 2 & Year 1 \\
Groundwater-magnitude of annual summer base flows & Year 3 & Year 1 \\
Lake ice-date of spring ice-out & Year 5 & Year 2 \\
River ice-winter days of ice-affected flow & -- & Year 2 \\
River ice-ice thickness for set winter date & -- & Year 2 \\
Snowpack-magnitude of late-winter water equivalent, depth, and density & & Year 3 \\
$\quad$ for set date & -- & Year 3 \\
Groundwater-winter recharge & -- & Year 3 \\
Groundwater-spring recharge & &
\end{tabular}

\section{Trend Updates for Key Variables}

It is important to not only collect data in a hydrologic climate-response program, but also to analyze the data on a regular basis. Many analyses of historical data for the key hydrologic variables included in this program have been completed (see Historical Hydrologic Changes in Maine section). As additional data are collected, existing historical analyses would be updated. New data would increase our understanding of year-to-year variability, decadal variability, and longer term changes. Trends in key variables would be updated on a rotating cycle.

Different cycles for updates would represent different levels of effort. For example, in a lower intensity effort, trend updates would be completed for five key variables at a rate of one variable per year (table 6), resulting in a 5-year cycle of updates for each variable. In a higher intensity effort, data for three variables per year would be analyzed, and the historical trends and variability for all variables (table 6) would be updated on a 3-year cycle.

\section{Process-Based Studies}

An important part of a hydrologic climate-response program in Maine would be to identify basins that are appropriate for use in process-based studies designed to understand and predict hydrologic and ecosystem change. The combination of extensive historical hydrologic data, ecological data, and deterministic watershed modeling would greatly increase our understanding of the effects of climate change on hydrologic components and ecosystem health.

For each region in the proposed hydrologic climateresponse program, a representative basin (for example, in geology and land cover) that has extensive historical data for multiple hydrologic components would be identified. Specific effort would be made to select candidate basins that contain important resources such as Atlantic salmon habitat and (or) Native American and U.S. Department of Interior or Agriculture lands. A deterministic watershed model would then be developed for each of these basins to improve understanding of basin hydrologic processes. The watershed models would use numerical methods to describe the physical processes that affect the movement of water throughout a basin. Runoff processes simulated by the models would include overland flow, shallow subsurface flow, and groundwater flow. Watershed models for multiple basins in Maine have already been completed or are being assembled (fig. 12).

The watershed models would be constructed using the USGS Precipitation-Runoff Modeling System (PRMS) (Leavesley and others, 1983). PRMS is well suited for simulating runoff from rural basins and has been applied to many basins in the United States. PRMS is a deterministic, distributed-parameter modeling system. The model is deterministic in that it computationally incorporates multiple components of the hydrologic cycle as understood through known physical laws or empirical relations in hydrologic science. The modeled hydrologic relations are typically governed by quantifiable physical characteristics of the basin. Parameters describing the physical basin characteristics are assigned in a distributed fashion, representing the spatial variation (heterogeneity) in basin characteristics. In this manner, the model is designed to simulate the hydrologic system as realistically as possible.

The models would be calibrated to the historical record. Calibrated watershed models provide simulated daily streamflow time series for many locations throughout a basin. The models leverage limited streamflow-gaging-station data and provide a method for characterizing sub-basin hydrology. An example of rainfall-runoff-model subareas for two basins in eastern coastal Maine is shown in figure 13. Model output provides information regarding surface runoff, subsurface flow, and groundwater flow because the model explicitly 


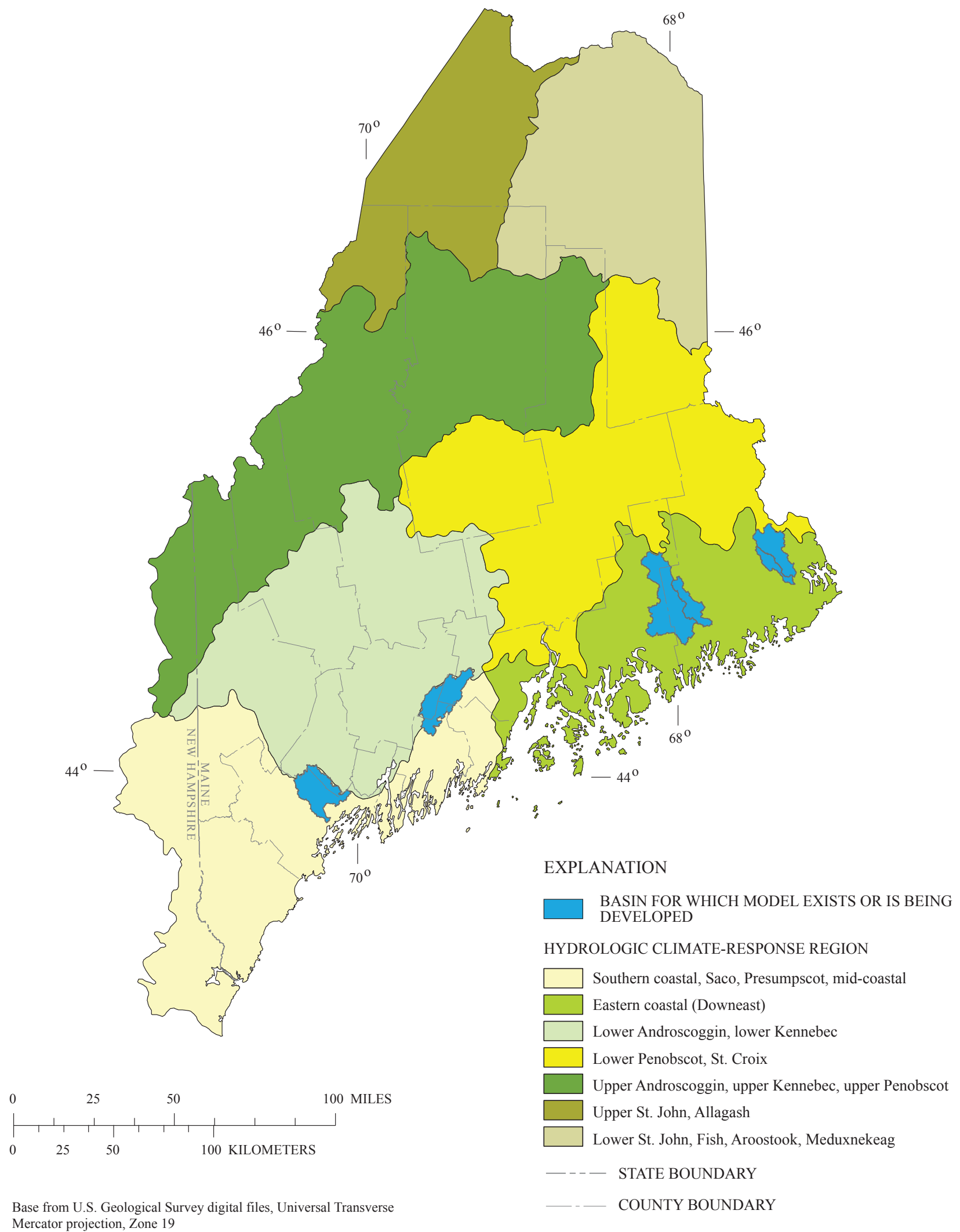

Figure 12. Location of drainage basins in Maine with rainfall-runoff models. 


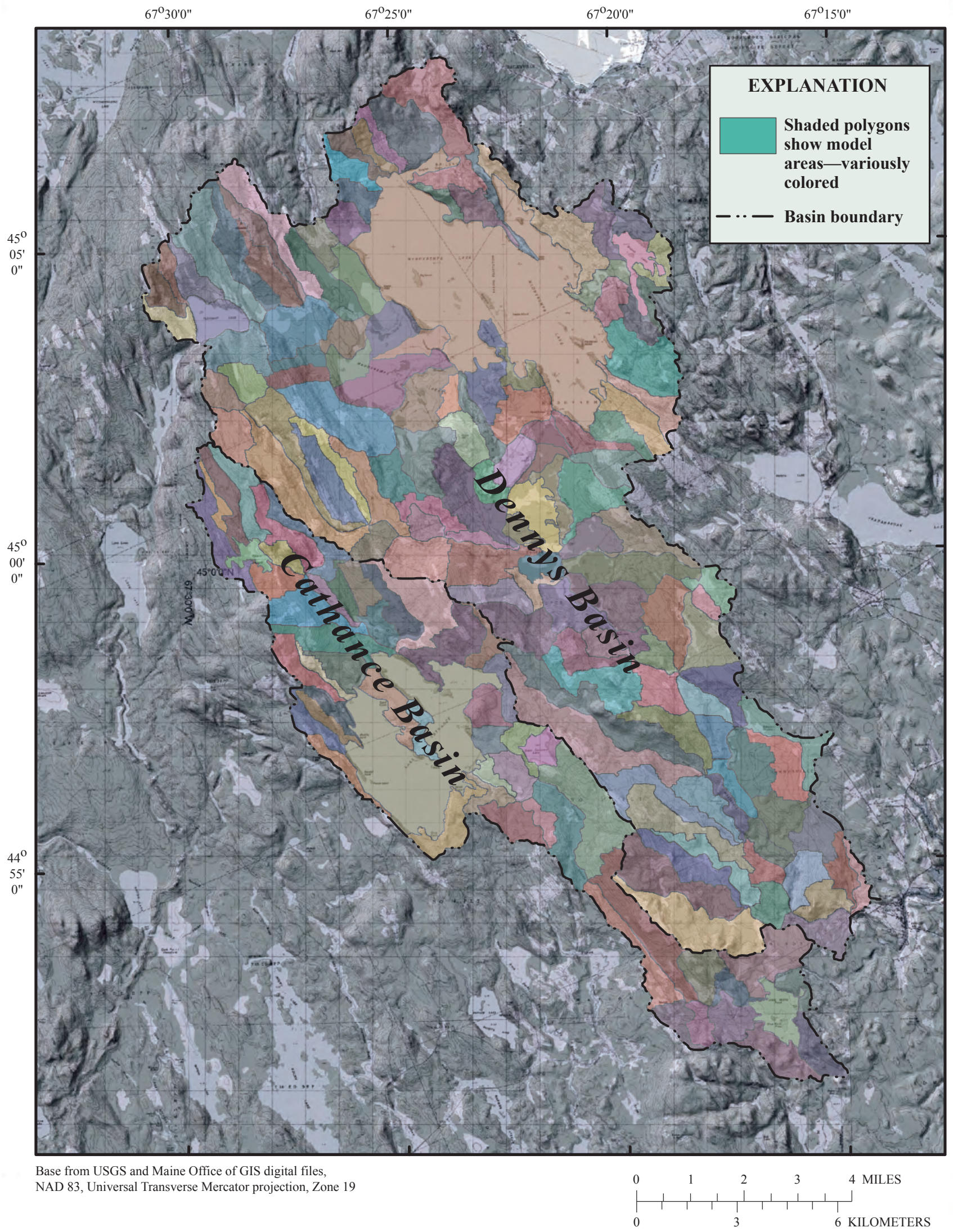

Figure 13. Rainfall-runoff model subareas for two drainage basins in eastern coastal Maine. 
simulates these physical processes. This information would enable natural-resource managers to characterize the timing and quantity of water moving through the basin to support many endeavors, including geochemical calculations, wateruse assessment, river biota population dynamics modeling, and habitat modeling and assessment. It also allows scenario testing for interactions between climate change and changes in water-use and land-use regulations.

Additional research would be conducted to improve understanding of important processes such as groundwater/ surface-water interactions, ice dynamics, and hydrologic/ ecological interactions for important habitats and species. For example, with improved availability of groundwater data, PRMS can be integrated with the USGS groundwater model, MODFLOW, in an application called GSFLOW (Markstrom and others, 2008) to support basin-scale groundwater/surfacewater resource investigations. Using models to characterize the relative contributions of surface water and groundwater to streamflow throughout the basin would lead to an improved understanding of water quantity and quality and the effects of future hydrologic changes on ecosystems in the basin.

\section{Communication Plan}

In order to be useful, the data and analyses from a USGS hydrologic climate-response program in Maine must be available to resource managers and to the public. A web site would be created to disseminate information regarding the design of the program, the data collected as part of the program, and interpreted historical-trend results. The trend results, as discussed in the Trend Updates for Key Variables section, would also be published on a regular basis, as USGS reports or journal articles.

\section{References Cited}

Beltaos, S., 2002, Effects of climate on mid-winter ice jams: Hydrological Processes, v. 16, p. 789-804.

Bradbury, J.A., Dingman, S.L., and Keim, B.D., 2002, New England drought and relations with large scale atmospheric circulation patterns: Journal of the American Water Resources Association, v. 38, p. 1287-1299.

Cember, R.P., and Wilks, D.S., 1993, Climatological atlas of snowfall and snow depth for the northeastern United States and southeastern Canada: Northeast Regional Climate Center Publication No. RR 93-1, Ithaca, New York, 213 p.

Collins, M.J., 2009, Evidence for changing flood risk in New England since the late 20th century: Journal of the American Water Resources Association, v. 45, p. 1-12.
Corbett, D.M., and others, 1943, Stream-gaging procedure, a manual describing methods and practices of the Geological Survey: U.S. Geological Survey Water-Supply Paper 888, $245 \mathrm{p}$.

Dudley, R.W., and Hodgkins, G.A., 2002, Trends in streamflow, river ice, and snowpack for coastal river basins in Maine during the 20th century: U.S. Geological Survey Water-Resources Investigations Report 02-4245, 26 p.

Dudley, R.W., and Hodgkins, G.A., 2005, Trends in timing, magnitude, and duration of summer and fall/winter streamflows for unregulated coastal river basins in Maine during the 20th century: U.S. Geological Survey Scientific Investigations Report 2005-5021, 26 p.

Grover, N.G., 1937, The floods of March 1936, Part 1. New England rivers: U.S. Geological Survey Water-Supply Paper 798, $466 \mathrm{p}$.

Hayhoe, K., Wake, C.P., Huntington, T.G., Luo, L., Schwartz, M.D., Sheffield, J., Wood, E., Anderson, B., Bradbury, J., DeGaetano, A., Troy, T.J., and Wolfe, D., 2007, Past and future changes in climate and hydrological indicators in the US Northeast: Climate Dynamics, v. 28, p. 381-407.

Hodgkins, G.A., Caldwell, J.M., and Dudley, R.W., 2003a, Historical dates of ice-affected flows for 18 rivers in New England: U.S. Geological Survey Open-File Report 03-245, $48 \mathrm{p}$.

Hodgkins, G.A., and Dudley, R.W., 2005, Changes in the magnitude of annual and monthly streamflows in New England, 1902-2002: U. S. Geological Survey Scientific Investigations Report 2005-5135, $37 \mathrm{p}$.

Hodgkins, G.A., and Dudley, R.W., 2006a, Changes in late-winter snowpack depth, water equivalent, and density in Maine, 1926-2004: Hydrological Processes, v. 20, p. $741-751$.

Hodgkins, G.A., and Dudley, R.W., 2006b, Changes in the timing of winter-spring streamflows in eastern North America, 1913-2002: Geophysical Research Letters, v. 33, L06402, doi:10.1029/2005GL025593.

Hodgkins, G.A., Dudley, R.W., and Huntington, T.G., 2003b, Changes in the timing of high river flows in New England over the 20th century: Journal of Hydrology, v. 278, p. $242-250$.

Hodgkins, G.A., Dudley, R.W., and Huntington, T.G., 2005a, Changes in the number and timing of days of ice-affected flow on northern New England rivers, 1930-2000: Climatic Change, v. 71, p. 319-340.

Hodgkins, G.A., Dudley, R.W., and Huntington, T.G., 2005b, Summer low flows in New England during the 20th century: Journal of the American Water Resources Association, v. 41, p. 403-412. 
Hodgkins, G.A., Dudley, R.W., and Loiselle, M.C., 2005c, Historical late-winter and spring snowpack depth and equivalent water-content data for Maine: U.S. Geological Survey Open-File Report 2005-1259, 80 p.

Hodgkins, G. A., and James, I. C. II, 2002, Historical ice-out dates for 29 lakes in New England: U.S. Geological Survey Open-File Report 02-34, 32 p.

Hodgkins, G.A., James, I.C. II, and Huntington, T.G., 2002, Historical changes in lake ice-out dates as indicators of climate change in New England, 1850-2000: International Journal of Climatology, v. 22, p. 1819-1827.

Hoyt, W.G., 1913, The effects of ice on stream flow: U.S. Geological Survey Water-Supply Paper 337, 77 p.

Huntington, T.G., Hodgkins, G.A., and Dudley, R.W., 2003, Historical trend in river ice thickness and coherence in hydroclimatological trends in Maine: Climatic Change, v. 61, p. $217-236$.

Huntington, T.G., Hodgkins, G.A., Keim, B.D., and Dudley, R.W., 2004, Changes in the proportion of precipitation occurring as snow in New England (1949 to 2000): Journal of Climate, v. 17, p. 2626-2636.

Krohn, W.B., Boone, R.B., and Painton, S.L., 1999, Quantitative delineation and characterization of hierarchical biophysical regions of Maine, Northeastern Naturalist: v. 6, p. 139-164.

Leavesley, G.H., Lichty, R.W., Troutman, B.M., and Saindon, L.G., 1983, Precipitation-runoff modeling system-User's manual: U.S. Geological Survey Water-Resources Investigations Report 83-4238, 207 p.

Loiselle, M.C., and Hodgkins, G.A., 2002, Snowpack in Maine-Maximum observed and March 1 mean equivalent water content: U.S. Geological Survey Water-Resources Investigations Report 01-4258, 19 p.

Maeda, O., and Ichimura, S.E., 1973, On the high density of a phytoplankton population found in a lake under ice: Internationale Revue der gesamten Hydrobiologie, v. 58, p. 673-685.

Markstrom, S.L., Niswonger, R.G., Regan, R.S., Prudic, D.E., and Barlow, P.M., 2008, GSFLOW-Coupled ground-water and surface-water flow model based on the integration of the Precipitation-Runoff Modeling System (PRMS) and the Modular Ground-Water Flow Model (MODFLOW-2005): U.S. Geological Survey Techniques and Methods book 6, sec. D, chap. 1, 240 p.

McCormick, S.D., Hansen, L.P., Quinn, T.P., and Saunders, R.L., 1998, Movement, migration, and smolting of Atlantic salmon (Salmo salar): Canadian Journal of Fisheries and Aquatic Science, v. 55 (Suppl. 1), p. 77-92.
Nakicenovic, N., and others, 2000, IPCC special report on emissions scenarios: Cambridge, U.K., and New York, Cambridge University Press.

National Oceanic and Atmospheric Administration, 2002, Climatography of the United States, no. 81: Monthly station normals of temperature, precipitation, and heating and cooling degree days, 1971-2000, Region 17, Maine, 16 p.

New England Regional Assessment Group, 2001, Preparing for a changing climate-The potential consequences of climate variability and change, New England regional overview: Durham, New Hampshire, University of New Hampshire, U.S. Global Change Research Program, 96 p.

Porter, K.G., Saunders, P.A., Haberyan, K.A., Macubbin, A.E., Jacobsen, T.R., and Hodson, R.E., 1996, Annual cycle of autotrophic and heterotrophic production in a small, monomictic Piedmont Lake (Lake Oglethorpe): Analog for the effects of climatic warming on dimictic lakes: Limnology and Oceanography, v. 41, p. 1041-1051.

Power, G., Cunjak, R., Flannagan, J., and Katopodis, C., 1993, Biological effects of river ice, in Prowse, T.D. and Gridley, N.C., eds., Environmental aspects of river ice, Saskatoon, Saskatchewan, Environment Canada, National Hydrology Research Institute.

Prowse, T.D., 1994, Environmental significance of ice to streamflow in cold regions, Freshwater Biology, v. 32, p. 241-259.

Prowse, T.D., and Beltaos, S., 2002, Climatic control of riverice hydrology: A review: Hydrological Processes, v. 16, p. 805-822.

Rantz, S.E. and others, 1982, Measurement and computation of streamflow: U.S. Geological Survey Water-Supply Paper 2175, 2 v.

Scrimgeour, G.J., Prowse, T.D., Culp, J.M., and Chambers, P.A., 1994, Ecological effects of river ice breakup: a review and perspective: Freshwater Biology, v. 32, p. 261-275.

Seaber, P.R., Kapinos, F.P., and Knapp, G.L., 1987, Hydrologic unit maps: U.S. Geological Survey Water-Supply Paper 2294, 63 p., 1 pl.

Slack, J.R., and Landwehr, J.M., 1992, Hydro-climatic data network (HCDN) - A U.S. Geological Survey streamflow data set for the United States for the study of climate variations, 1874-1988: U.S. Geological Survey Open-File Report 92-129, 193 p.

Sloto, R.A., and Crouse, M.Y., 1996, HYSEP: A computer program for streamflow hydrograph separation and analysis: U.S. Geological Survey Water-Resources Investigations Report 96-4040, 46 p. 
Stewart, K.M., 1976, Oxygen deficits, clarity and eutrophication in some Madison lakes: Internationale Revue der gesamten Hydrobiologie v. 61, p. 563-579.

U.S. Environmental Protection Agency, 2007, Level III ecoregions of the continental United States map.

Wuebben, J.L., Deck, D.S., Zufelt, J.E., and Tatinclaux, J.C., 1995, Ice jam flood assessment for the St. John River Basin, Aroostook County, Maine: U.S. Army Cold Regions Research and Engineering Laboratory Special Report 95-15, $22 \mathrm{p}$. 

응

ฏ.

E

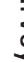

존

윽

음

○

急

s

品

꿍

응 